\title{
قياس السلوك العدواني لدى الأطفال وعلاقته ببعض المتغيرات
}

\section{د.أسيل عبد الكريم الشئمري}

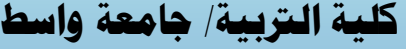

1 - 1 - 1 مشكلة البحث :-

تعد مشكلة العدوان من المشاكل المهمة التي لها أثز في تعطيل العملية التزبوية، فهي إحدى المشكلات التي تعـاني

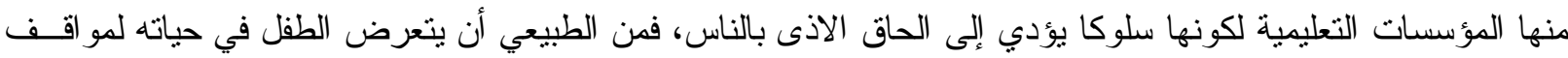
يكون عليه أن يدافع عن نفسه فيها بطريقة عنيفة در ءا لعدوان الآخرين عليه وهذه مو اقف طبيعية لا توصف بالعـدوان اذ إن الطفل يغضب اذا اعتدي على مدنلكاته، فهذا السلوك عادي في مرحلة الطفولة الأولى لكن حينما تلازم الطفـلـل لـسنين

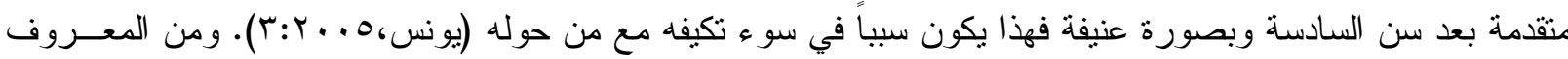
انه لبس هناك شخصان متشابهان تماما، وهذا يرجع إلى اختلاف سلوك الناس تجاه كل موقف من مواقف الحياة، بـلـل ان

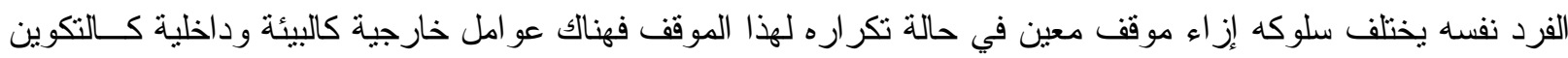

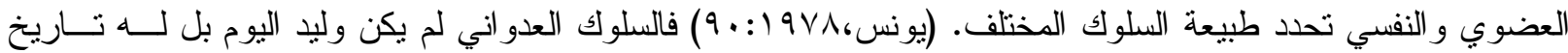

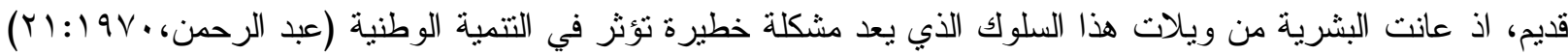

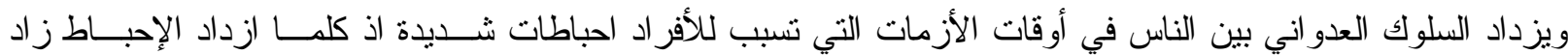

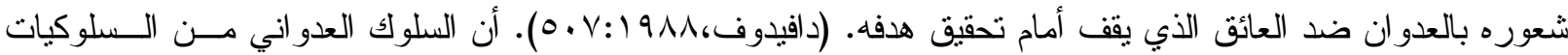
اللاسوية وهو ذو أبعاد عدو انية خطرة على الطفل وعائلته ومدرسته بخاصة و على الحياة الاجتماعية و المجتمع بشكل عام،

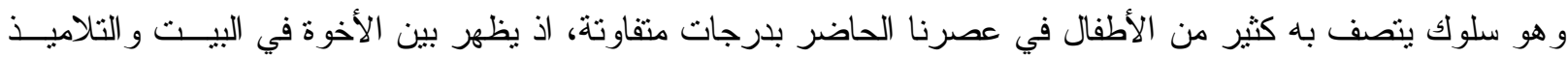
و الطلبة في المدارس، لذا تتحدد مشكلة البحث في التعرف على السلوك العدو اني بين الأطفال، وهل يختلف بحسب متغيــر الجنس و العمر ، فهذا التساؤل يمثل بدوره مشكلة بحاجة إلى إجابة علمية دقيقة يمكن التوصل اليها من خلال هذا البحث.

\section{r - r أهمية البحث و الحاجة اليه :}

تأتي أهمية البحث من خلال ما تهدف اليه التربية وهو الاهتمام بالطفل لكونه المحور الأساس الذي تدور حولـــه العمليــة الثربوية. (صغير ، QNV، (Y)، فالعدوان يؤثر في تعليم الطفل في المرحلة الابتدائية ويعطل رغبته في التعلم و التعليم ويؤثز في تزكيزه، اذ نجد ان العدوان لدى الأطفال في السنة الأولى حتى الخامسة يتكون نتيجة التغيــر ات النفـــية و الجـسمية

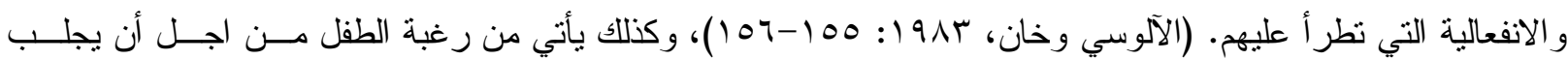

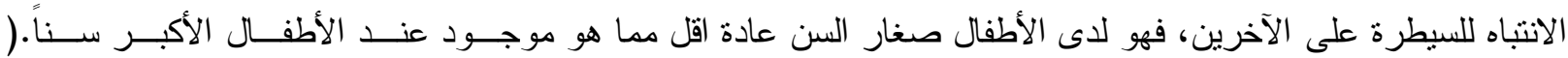
rع r:Hurlock,1964 )، ولذا نالت ظاهرة العدوان اهتمام الإنسان اذ اهتم بها الفلاسفة ورجال الدين و المفكرون قـديماً و علماء الاجتماع و علماء النفس حديثاً (كمال، 9A1:V09 (1)، و العدوان كغيره من مظاهر السلوك الإنساني لابد أن يخــدم

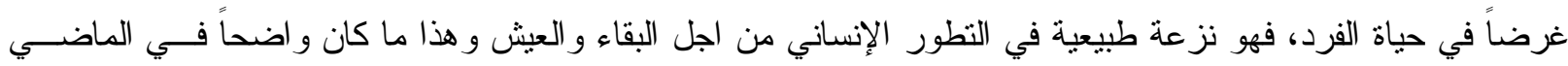

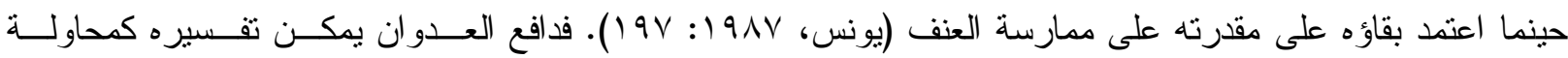

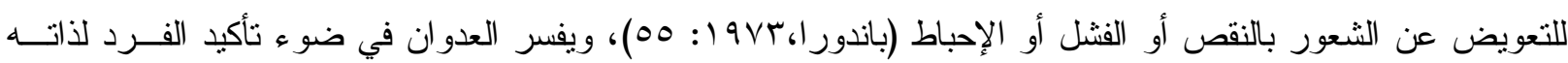
بالسيطرة على الآخرين و هذا يتم من خلال قونه البدنية في عقاب الآخرين و إبذائهم. (ستور ، 9 ( إسب). ان الله سبحانه وتعالى خالق الكون بأكمله ومن خلقه وتكوينه انه خلق أصعب المخلوقات هي النفس الإنسانية، وخلــق

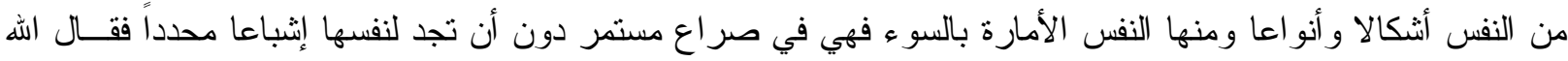


سبحانه وتعالى:(وذكر به أن كل نفس بما كسبت) وقال الأمام علي(ع) (سوء الأدب سبب كل شر ). و اذا انفلتــ الأمــور

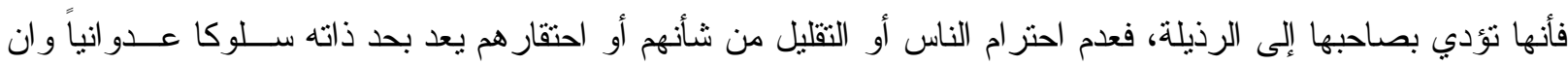

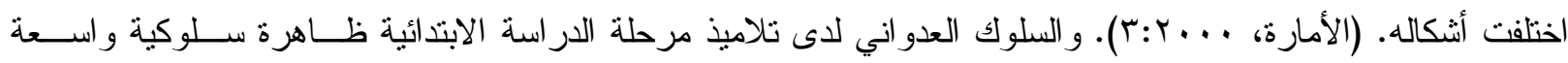
الانتشار ، و هذا السلوك يؤدي إلى الفوضى داخل صف الدر اسة، وينعكس أثزه على المعلم و التلاميذ، اذ ينخفض أداء المعلم

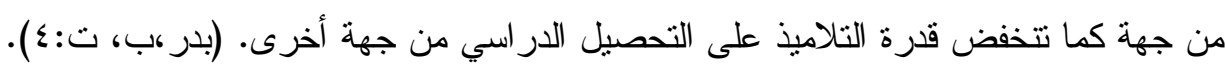

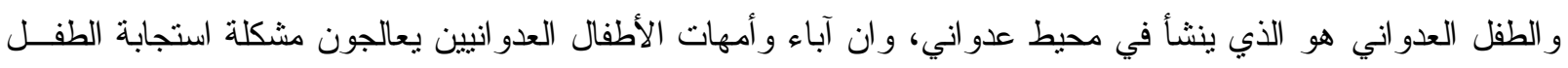

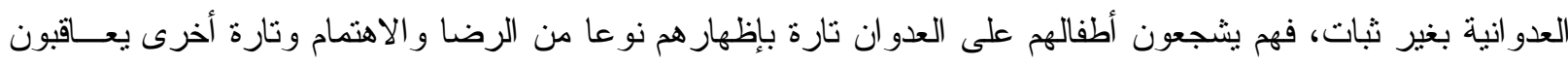

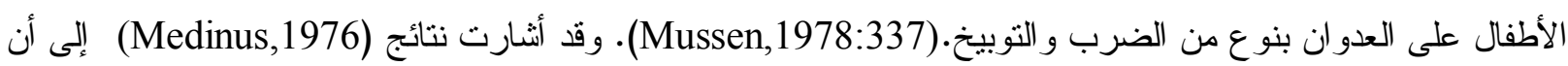
الآباء لهم اثز و اضح في تطور السلوك العدو اني لكونهم سبياً للإحباط أكثر من الأمهات. (Medinus:1976:384)، و وأما در اسة (Hiram,etal,1989) أشنارت إلى طبيعة العلاقة بين السلوك العدواني الذي يعامل به الو الدان أبناءهم و المشكلات السلوكية لهؤلاء الأبناء، اذ توصلت إلى وجود علاقة ارتباطية موجبة بين السلوك العدواني الذي يعامل به الو الدان أبناءهم

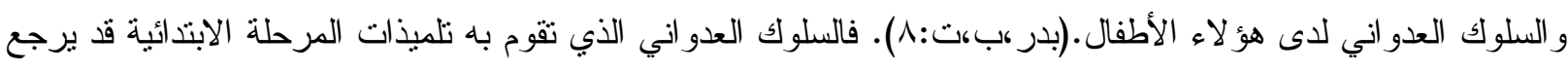

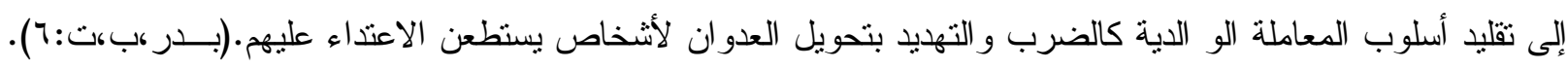

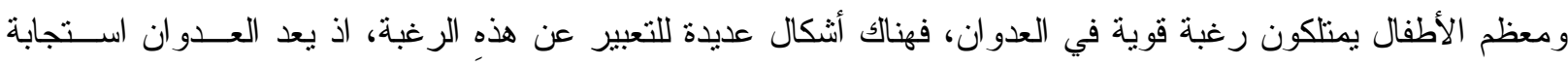

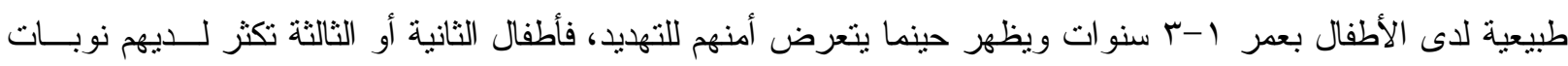
الغضب، أما الأطفال بعمر 0-ـ سنوات يستعملون العدوان البدني و اللفظي دون وجود نوبات حادة من الغضب، وان الذبي يساعد الأطفال على نمو السلوك العدواني لديهم هو طريقة الو الدين في نتشئتهم اذ لها اثز كبير في نمو منل هذا الـسلوك.

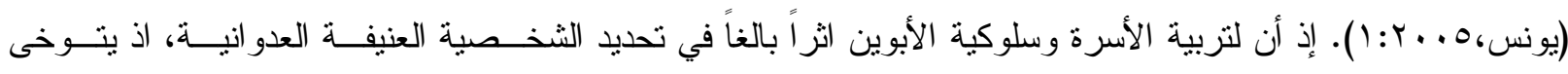

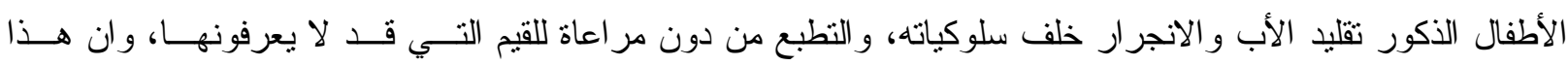

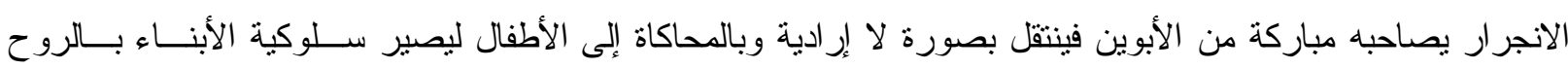

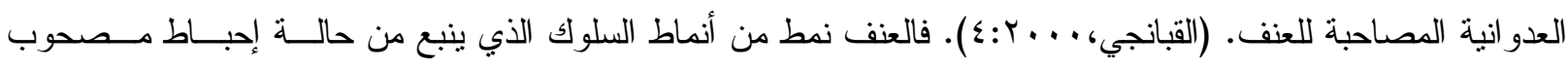

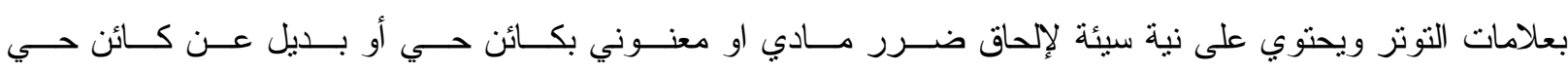

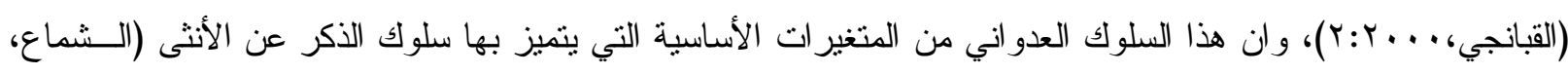

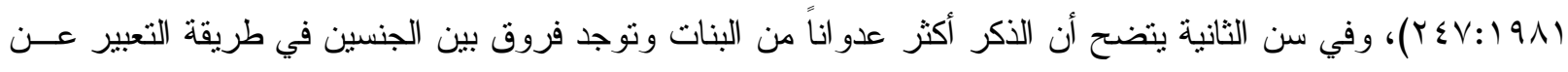

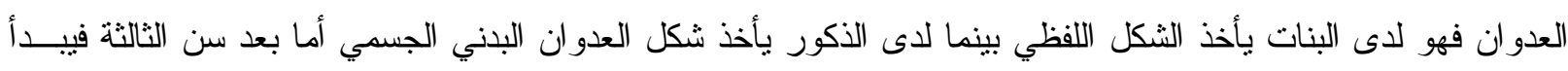

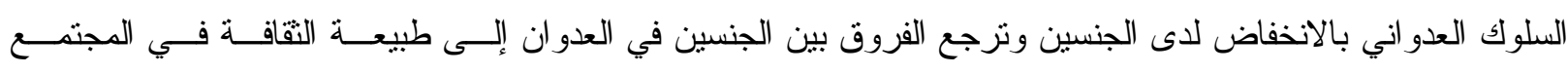

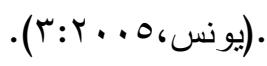

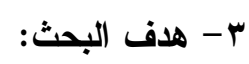

يستهدف البحث الحالي إلى قياس السلوك العدو اني لدى الأطفال بسب متغير

$$
\begin{aligned}
& \text { 1- العمر (7، 1، ، • 1 ) سنة. } \\
& \text { r- الجنس (ذكور - إناث). } \\
& \text { ع - فرضيات البحث : }
\end{aligned}
$$

ا - لا يوجد فرق دال احصائياً في متوسط درجات السلوك العدو اني لاى الأطفال بسبب متغير الجنس(ذكور - إناث). 
ץ- لا يوجد فرق دال احصائياً في متوسط درجات السلوك العدو اني لدى الأطفال بـسبب متغيــر العـــر (7،^، • ()

$$
\text { ه- حدود البحث : }
$$

يقتصر البحث الحالي على تلاميذ الصف الأول، و الثالث، و الخامس الابتدائي وبأعمار (T،^،، • ( ) سنوات في محافظة

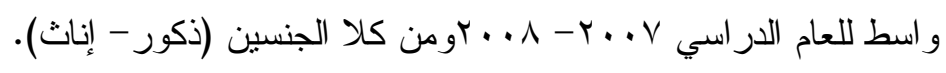

تحديد المصطلحات:

ا- القياس Measurement: يعرفه اييل (Eble) بأنه عملية مقارنة بعض خصائص الثيء بوسيلة مقننة أعـدت سـلفاً

لقياس تلك الخاصية.,Ebe1972P:122)1).

ويعرفه بر اد فيلد (Brad Field) بأنه عملية تحديد النواحي الكمية المرتبطة بحجم و أبعاد الظاهرة المقيسة لينسنى وصفها

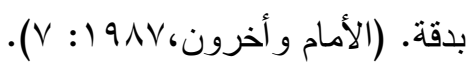

التعريف النظري: وصف البيانات و المعلومات باستخدام لغة التكميم (الأرقام) لظاهرة أو سمة معينة وفق مقياس معين. التعريف الإجر ائي : تقدير السلوك العدواني تقدير اً كمياً وفق مقياس أعد لهذا الغرض.

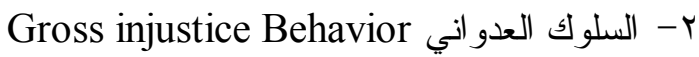

- تعريف كود Good: هو نشاط معاد يثير الخوف أو الهلع في المخلوق الآخـر وهــو نــاجم عـن الإحبـاط Good )

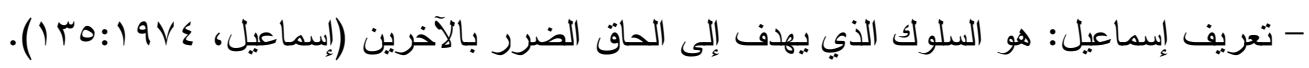
- تعريف عبود

هو السلوك الذي يؤدي إلى ألحاق الاذى و الدمار بالآخرين بالفعل أو بالكلام، والجانب السلبي منه يعني ألحـاق الاذى

$$
\text { بالذات (عبود (199 1: . 1) }
$$

- التعريف النظري: هو سلوك يهدف إلى إيذاء الناس سو اء أكان بالكلام أم بالضرب و التشاجر مع الآخرين.

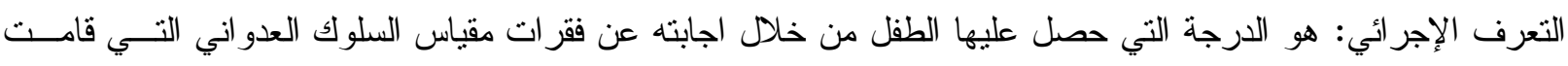
الباحثة بأعداده.

ץ- الأطفال: تعرفهم الباحثة إجر ائيا بأنهم أولئك الأفراد المستمرون بالدراسة في الصف الأول الابتدائي وبعمر 7 سنوات وفي الصف الثالث الابتدائي بعر ^ منوات وفي الصف الخامس الابتدائي بعمر • اسنوات.

الإطار النظري ودر اسات سابقة أولاًا - الإطار النظري: الإطري

$$
\text { أ- أقسام السلوك العدو اني لدى الألى الأطفال في عمر المدرسة : }
$$

ب- العدوان الموجه نحو الذات: يحدث هذا العدوان لاى الأطفال المضطربين سلوكياً إذ يوجهون عدوانه النه نحو الذات

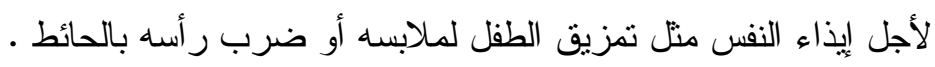

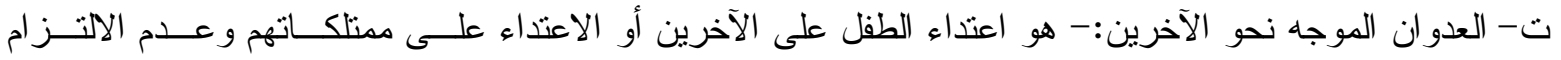

$$
\begin{aligned}
& \text { بالسلوك المقبول اجتماعياً. (عبود، (1991: 11) (1). } \\
& \text { r - العوامل المرتبطة بالسلوك العدواني: }
\end{aligned}
$$


أ- الغريزة : يعتقد أصحاب نظرية التحليل النفسي أن العدوان ظاهرة سلوكية غريزية وهو ليس ســلوكاً غريزيــاً أو فطريا فحسب بل هو حتمي، و إذا لم يسنطع توجيه العدوان نحو الآخرين فانه سيوجهه نحو ذاته، و هو في ذاته بــنجم

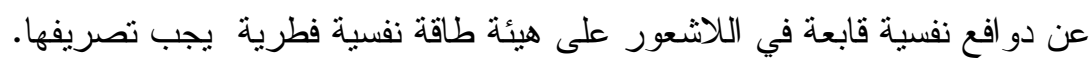
ب- العو امل البيولوجية: أن العلاقة ارتباطيه موجبة بين العدوان و الاضطر ابات الهرمونية العصبية و الكروموسومية،

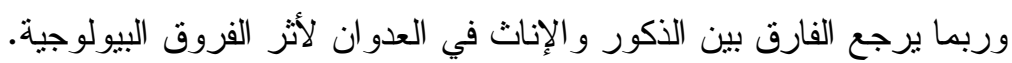
ج- العو امل البيئية: نزيد العو امل البيئية مثل الضوضاء وارتفاع درجة الحرارة من احتمالية السلوك العدواني.

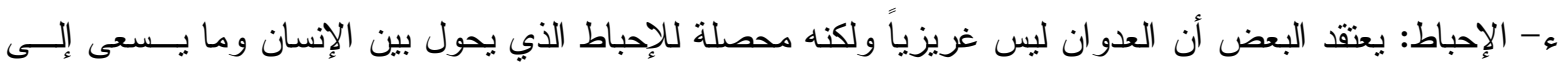
تحقيقه، بذلك يشكل الإحباط حافز اً للعدوان. هـ- التعليم : بينت النظرية السلوكية اثر الخبرات و الملاحظة و المواقف التعليمية الاشتر اطية على السلوك العـدو اني

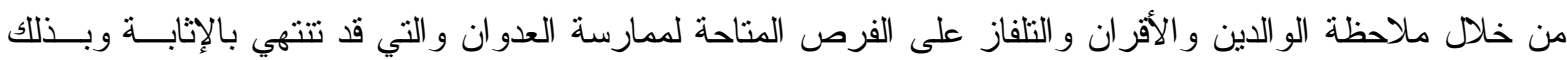
يكون العدوان ظاهرة سلوكية يتعلمها الإنسان. و - عو امل أخرى: كالجنس فالذكور أكثر عدوانية من البنات لعوامل بيولوجية ونفسية، كما برتبط العدوان بعدم القدرة

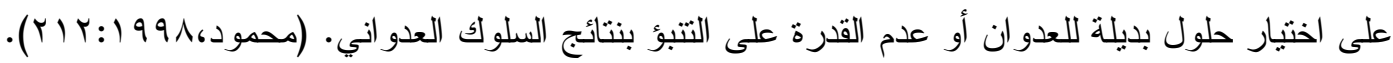

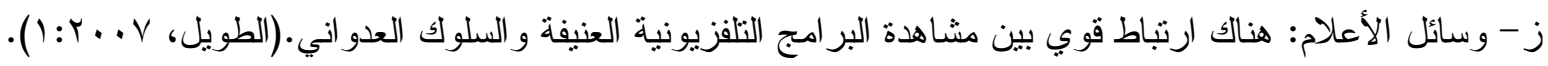
r- أسباب ظهور السلوك لدى الأطفال وطرائق معالجته:

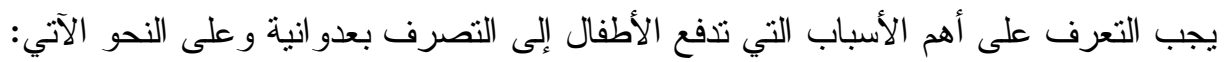

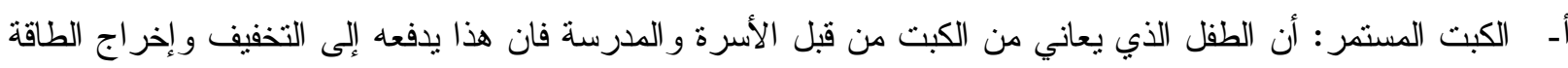
الكامنة لديه لتظهر على شكل عدوان مادي أو معنوي.

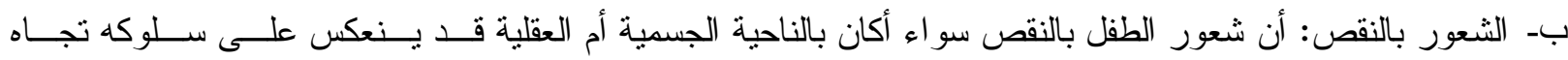
الآخرين.

ج- الفثل و الإحباط المستمر : أن الفشل المتكرر في شؤون الحياة يؤدي إلى التصرف بعدو انية كردة فعل تجاه ذلك.

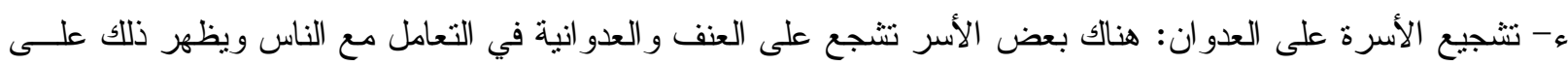

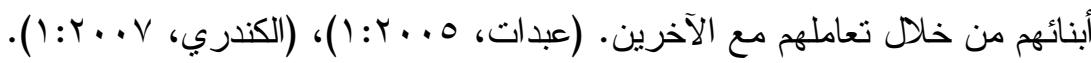

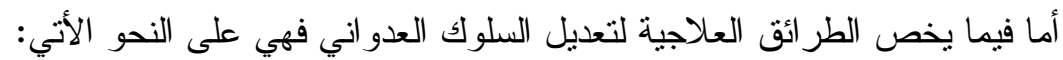
1- الإقصاء أو العزل عن التعزيز الايجابي. r- تكلفة الاستجابة.

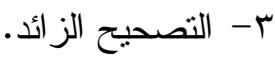

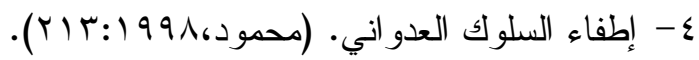
0- تجنب الممارسات و الاتجاهات الخاطئة في تتشئة الطفل. צ- الإقلال من التعرض لنماذج العنف التي يتم مشاهدتها بالتلفاز . - V العمل على خفض مستوى النز اعات الأسرية.

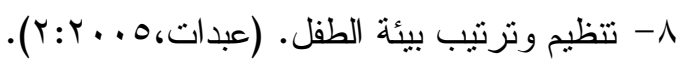
ع - نظريات السلوك العدوان: 
تباينت وجهات النظر في تفسير السلوك العدواني، و العو امل المؤثرة فيه، منلما تباينت في تفسير أنمــاط الــسلوك

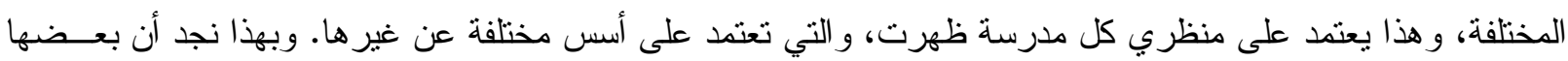
عدَّ هذا السلوك سلوكاً فطرياً يولد مع الإنسان، أما البعض الأخر فعده سلوكاً مكتسباً تم تعلمه من البيئة التي يعيش فيها. رأي النظرية السلوكية في العدوان: أكد السلوكيون على أهمية المؤثرات البيئية، وأعطو التدريب الهئه الهماماً بالغاً في خلق العادات نتيجة التكر ار، فالتـدريب

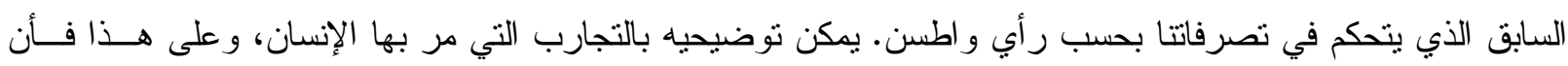

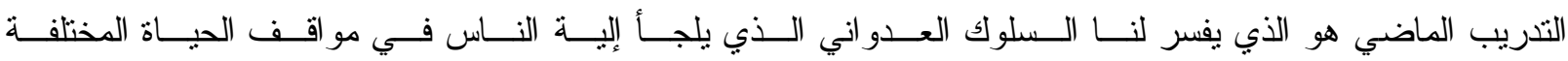
(عويس، (1919:194) (1910) رأي النظرية الاجتماعية في العدوان: أنثار منظروا التعلم الاجتماعي إلى أن تعلم العدوان يأتي من ملاحظة النماذج العدوانية، وكذللك من عمليات التعزيز التي التي

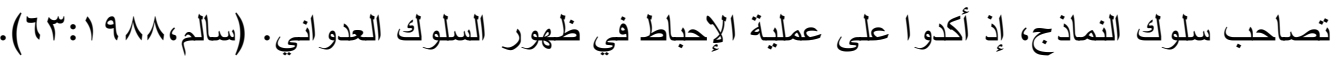

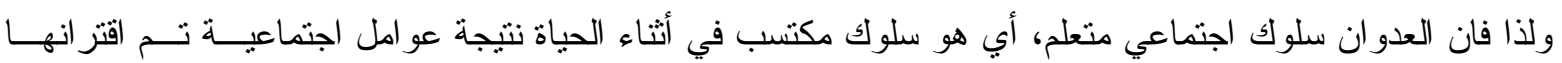

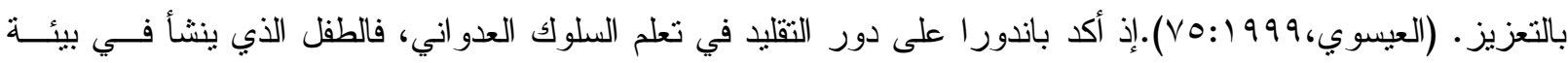

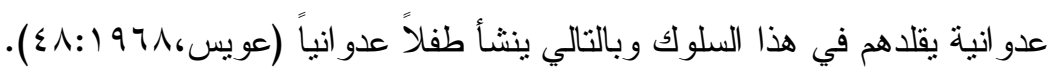
رأي النظرية الايثولوجية:

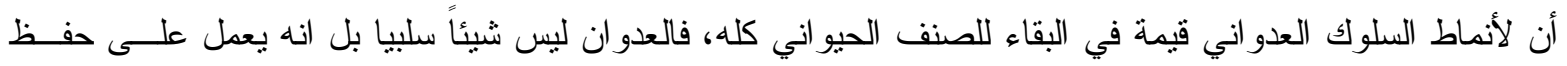

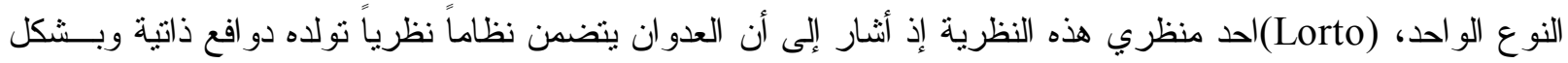

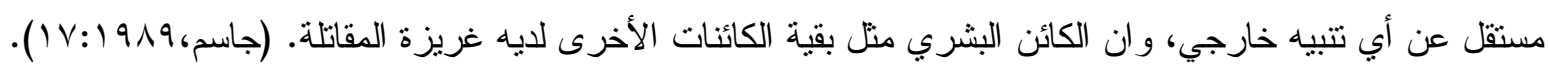
رأي المدرسة العقلية في العدوان:أثنار علماء النفس العقلي إلى دور الأفكار والمعتقدات على السلوك، إذ وجد أن المر اهقين العدو انيين كانوا قد تعرضـــوا

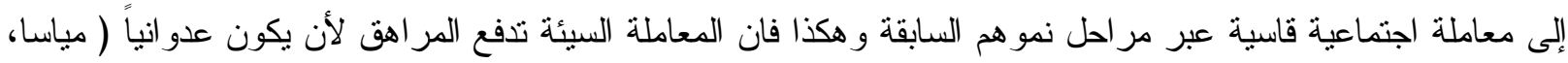

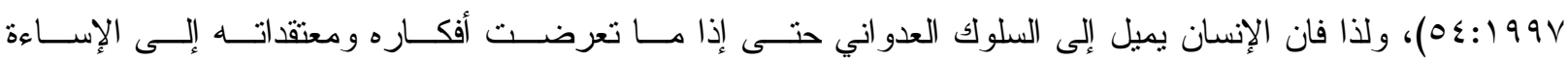

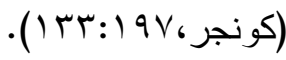

\section{نظرية الإحباط - العدوان:}

يعد دو لارد (Dolard) احد منظري هذه النظرية، إذ أثنار إلى أن العدوان لا يصدر عن غريزة، بـلـل يكـــــ نتيجـــة

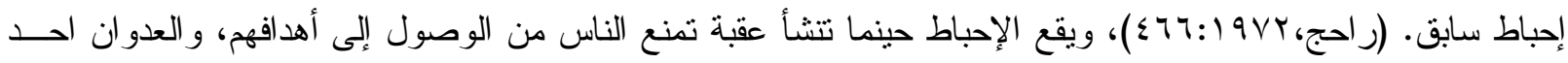

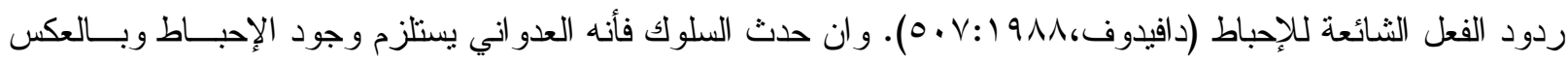

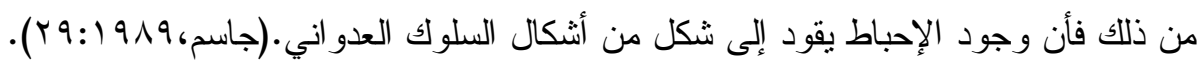
رأي علم النفس التحليلي في العدوان:

يرى فرويد أن الميل إلى العدوان و التدمير استعداد غريزي أي دافع فطري كالجوع و العطش يحتمه التكوين العضوي

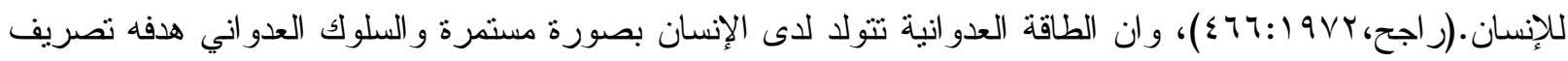

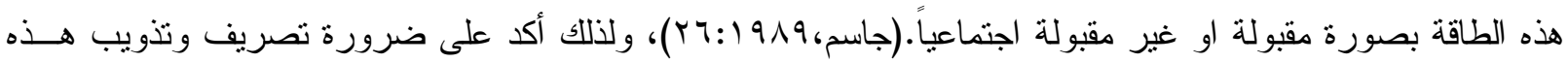

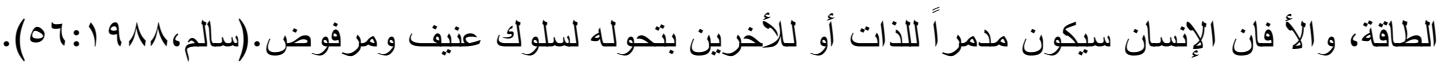


مناقشة الإطار النظري:

من خلال استعر اض الإطار النظري للبحث الحالي اتضح أن هنالك وجهات نظر عديدة تهــتم بتفـــير وتحليــل

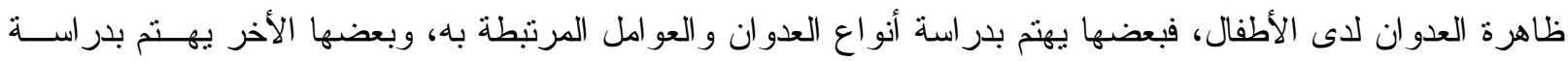

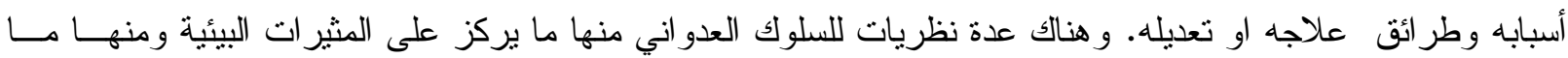
يركز على المثيرات الور اثثية ومنها ما يجمع بين دور البيئة و الور اثثة في إحداث السلوك العدو اني. وفي ضو ء ما تقدم فان الباحثة تبنت نظريات السلوك العدو اني التي تفسر العدوان في ضوء المثير لئه ات البيئة المختلفة. جو انب الاستفادة من الإطار النظري: أسهم الإطار النظري في: 1- بلورة وتحديد مشكلة البحث الحالي.

r- r تحديد بعض فقرات مقياس السلوك العدو اني لدى الأطفال. ثانياً - در اسات سابقة: أ- در اسات عربية:

1- در اسة صغير 19AV الموسومة بـ(علاقة السلوك العدو اني ببعض المتغير ات العائلية لدى تلاميذ الــصف الخــامس

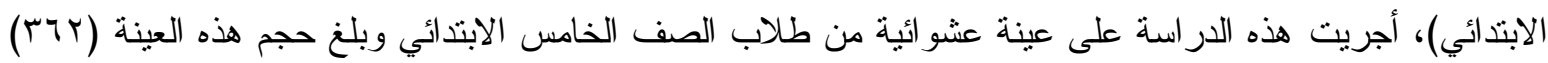

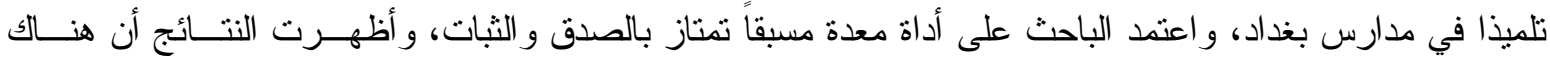

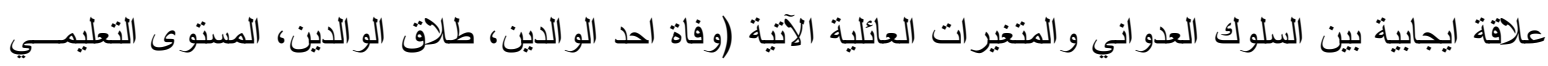

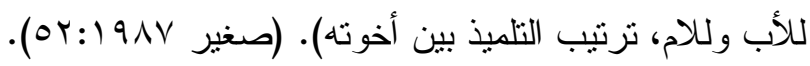

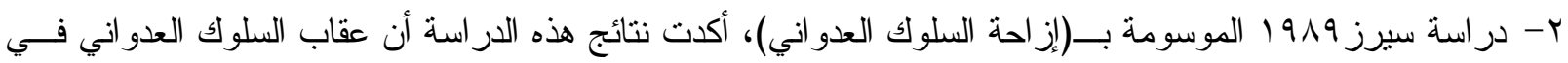

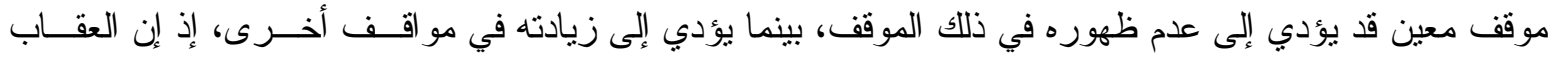

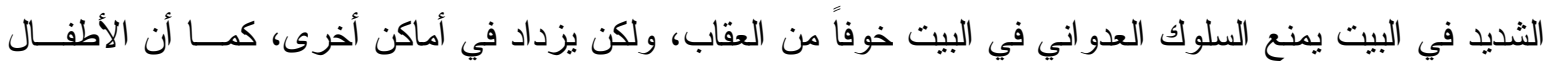
الذين عوقبوا على عدوانهم في اللعب كانو ا اقل عدو اناً في اللعب من الأطفال الذين لم يعاقبوا، في حين أن الأطفــال

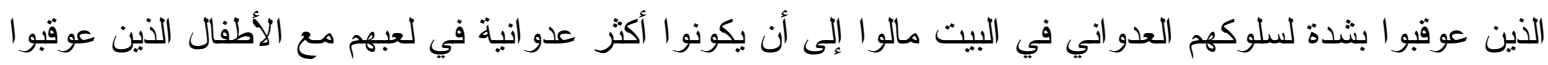

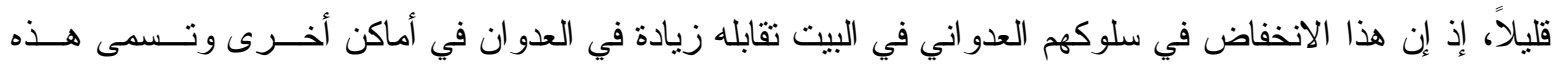

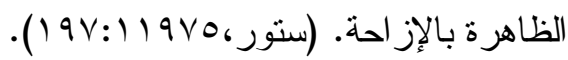
r- در اسة الحلو 1997 الموسومة بــ(السلوك العدو اني للمر اهق و علاقته بجنسه وعمره و الضغوط النفسية التي يتعرض

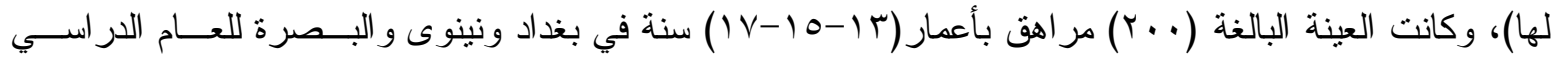

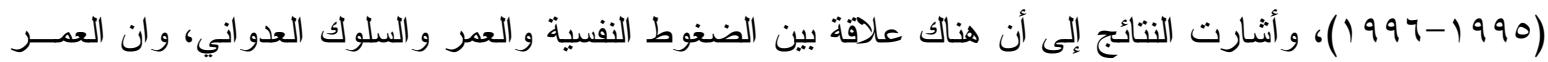

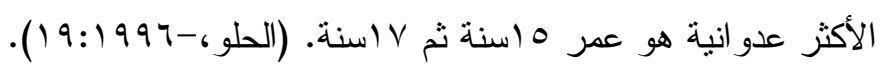

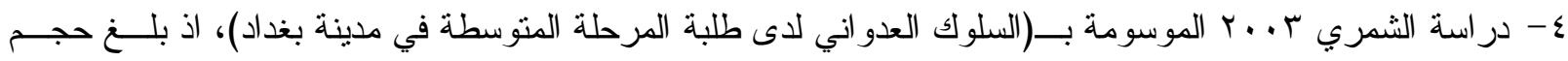

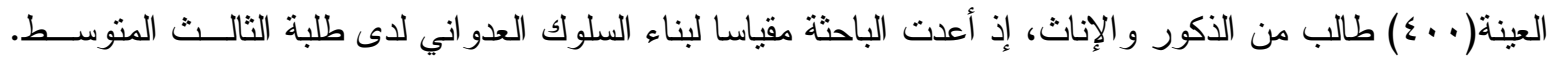
و أثنارت النتائج إلى وجود السلوك العدو اني لدى طلبة الصف الثالث المتوسط، إذ ان معظم الطلبة لديهم هذا الـسلوك لـوك

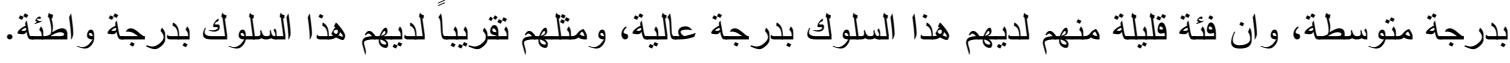

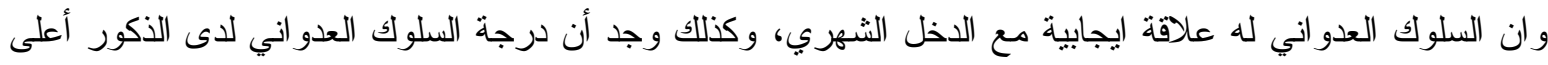

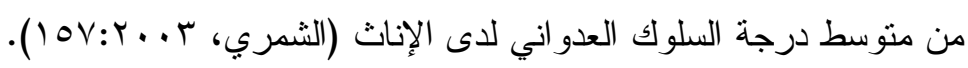


ه- در اسة علي r .. rالموسومة (السلوك العدواني وعلاقته بالذكاء و الجنس لدى تلاميذ الصف الأول الابتدائي الملتحقين

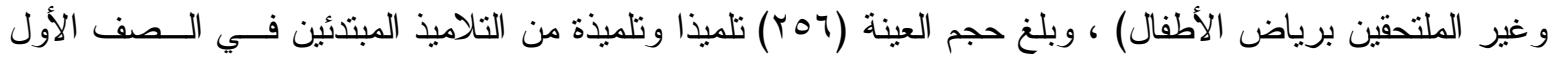

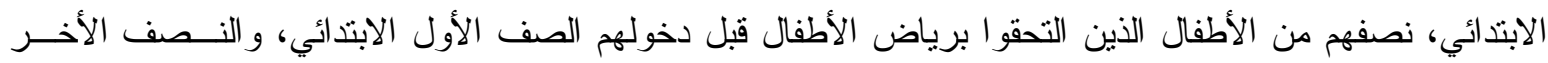
ممن لم يلتحقو ابرياض الأطفال قبل دخولهم الصف الأول الابتدائي، و أنشارت النتائج إلى أن مستوى السلوك الإند العدواني

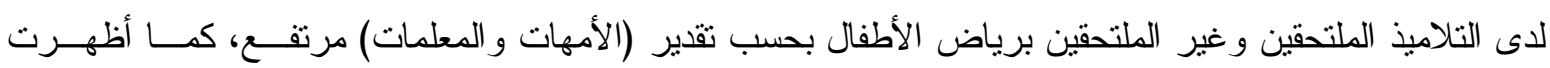

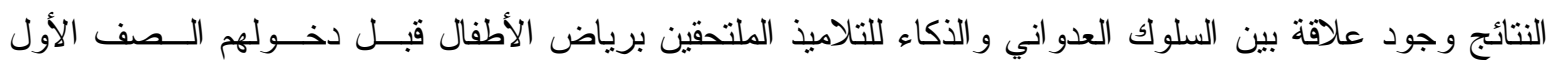

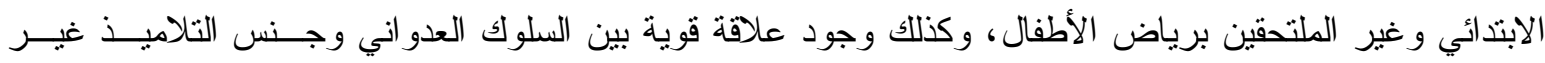

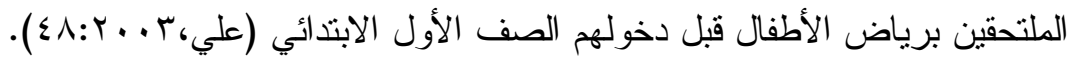

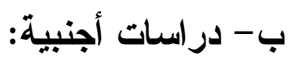

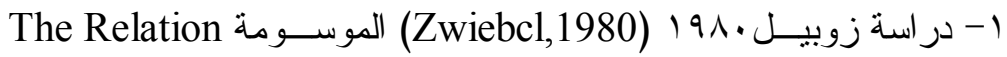
Between Matcrnal Behaviours and aggression in sons Blaok and puer to Rican Families) بلغ حجم العينة (1) طفلاً و أثنارت النتائج إلى أن أمهات الأولاد العدو انيين قد حققت بصورة ملحوظة درجـات

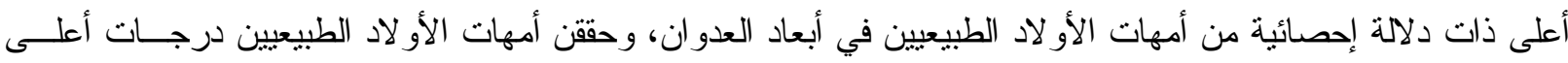
ذات دلالة إحصائية من أمهات العدو انيين في متغير الألفة الاجتماعية (Zwiebcl,1980:49).

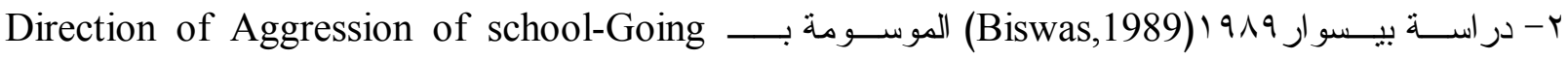
(Adolescents .Related to Family).

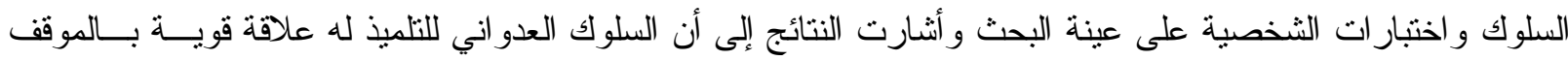

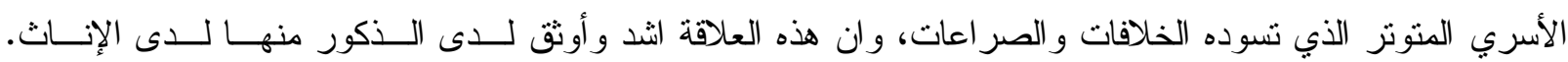

- (Biswgs:1989P:1-2)

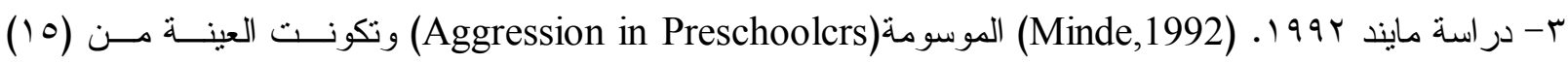

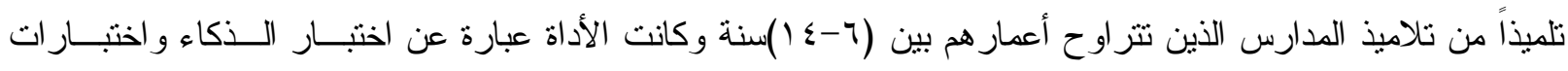
الثخصية، ونوصلت الدراسة إلى أن ليس جميع الأطفال المنتمين إلى اسر عنيفة بتصرفون بشكل عنيف فـي المدرســة، وينوقف ظهور السلوك العدواني عندهم على بعض صفاتهم الشخصية.(Minde,1992P:31 ). مناقشة الار اسات السابقة:

تباينت الدر اسات السابقة فيما بينها في مجال مشكلة البحث و أهدافه و إجر اءاته لا سيما في مجتمــع البحــث و عينتــــ و ادو اته ووسائله الإحصائية إذ كانت اكبر عبنة في در اسة الثمري ب . . بفقد بلغت ( . . ع) فرد.

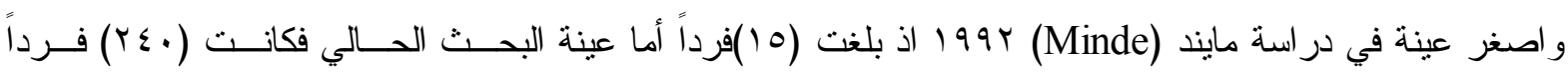
وبعض هذه الدر اسات استخدم مقاييس للسلوك العدو اني واختبار ات الثخصية العدو انية وبعضها استعمل أسلوب الملاحظة

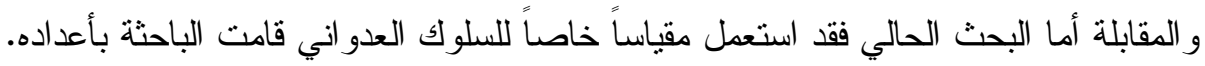
جوانب الإفادة من الاراسات السابقة: إفادة الباحثة من الدر اسات السابقة في تحديد إجر اءات البحث ومنهجيته و الإفادة من بعض توصياته ومقترحاته.

$$
\text { أولاً - مجتمع البحث : البحث: }
$$




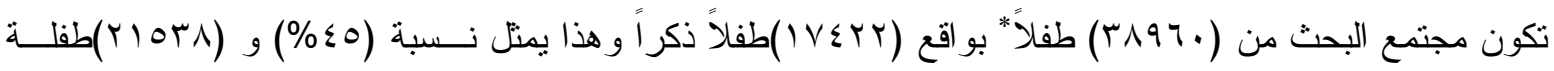

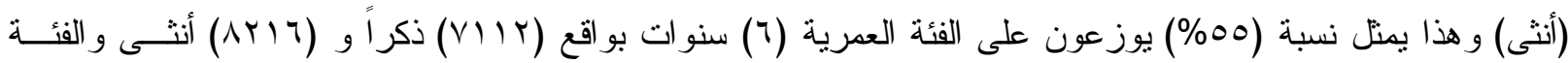

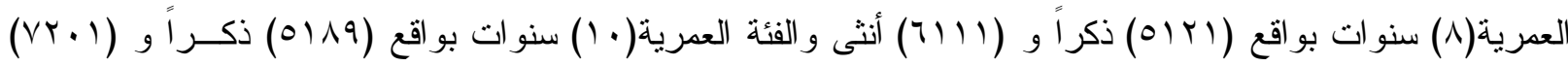

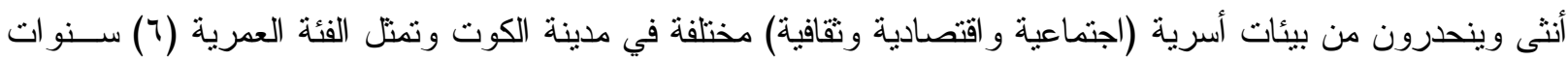

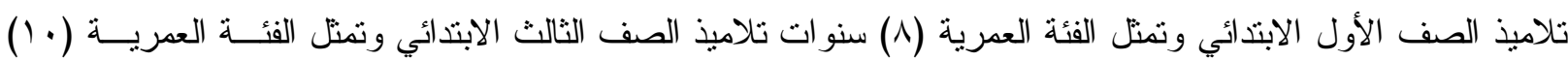
سنوات تلاميذ الصف الخامس الابتدائي. و الجدول (1) (يوضح ذلك. (1) جدول

يوضتح طبيعة مجتمع البحث موزعة بحسب منغير العمر والجنس

\begin{tabular}{|c|c|c|c|c|}
\hline الجموع & عمر ·ل سنوات & عمر ^ سنوات & عمر 1 سنوات & الجنس / الفئة العرية \\
\hline IVETr & $01 \wedge 9$ & $0 / r 1$ & VIIr & ذكر \\
\hline rors & VT. & 7111 & ArIT & أنثى \\
\hline$\Gamma_{\wedge} 99$. & $1, \leqslant \leq$. & lirtr & lorrA & المجموع \\
\hline
\end{tabular}

ثانياً - عينة البحث :

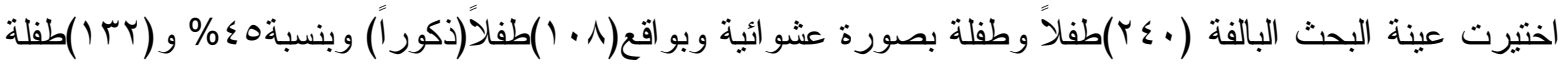

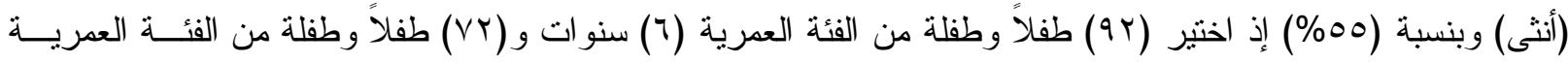

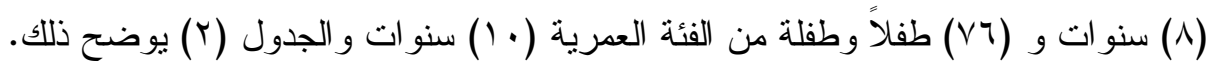

جدول (r)

يوضح طبيعة عينة البحث موزعة بحسب متغير العمر والجنس

\begin{tabular}{|c|c|c|c|c|}
\hline المجموع & عمر ·. سنوات & عمر ^ سنوات & عمر 7 سنوات & الجنس / الفئة العمرية \\
\hline $1 \cdot 1$ & Tr & r & $\varepsilon \varepsilon$ & ذكر \\
\hline rTI & $\varepsilon \varepsilon$ & $\varepsilon$. & $\varepsilon \wedge$ & أنثى \\
\hline$r \leq$. & $V_{T}$ & VY & 94 & المجموع \\
\hline
\end{tabular}

ثالثاً - أداة البحث: لتحقيق هدف البحث الحالي وعدم نو افر أداة مناسبة لقياس السلوك العدواني لاى الأطفال بحسـسب علـــ الباحثة وخبرتها المتو اضعة ارتأت أن تقوم بإعداد مقياس مناسب تتو افر فيه خصائص المقياس الجيد كافة من صدق وثبات وموضوعية كالآتي: أ- إجراعات بناء المقياس:

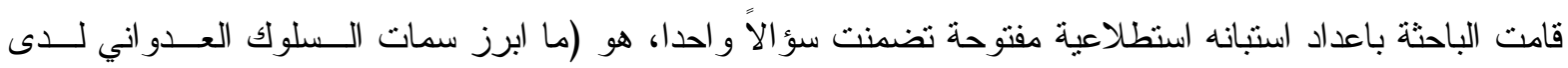

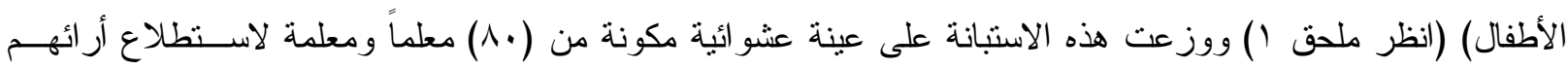
بشأن سمات السلوك العدو اني لاى الأطفال وبعد الانتهاء من هذا الاجر اء، قامت الباحثة بتتظيم وترتيب فقر ات الاسـنتبانة المغلفة معتمدة على بعض ما جاء في الأدبيات و الدر اسات السابقة في هذا المجال ومقابلة عينة من أولياء أمـــور الأطفــال بلغ عددهم (·r) ولي أمر بهدف محاورتهم والكثف عن أهم صفات السلوك العدو اني لاى الأطفال ثم حلت نتائج الدر اسة الاسنطلاعية التي هدفت إلى الكثف عن صفات (سمات) السلوك العدواني لاى الأطفال، فتوصلت الباحثة بشكل أولي إلى لى لهـ لهن

* حصلت الباحثة على هذه الإحصائية من مديرية تربية واسط/ قسم التخطيط التربوي للعام الدر اسي V . . r/ . . rم. 


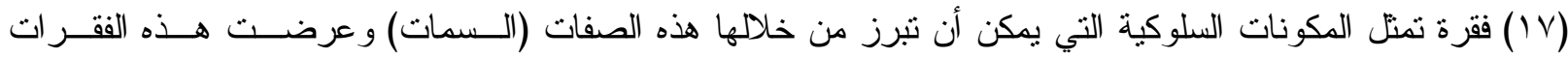
(المكونات السلوكية)على لجنة من الخبر اء* بحضور الباحثة بهدف التحقق من صحة تحليل نتائج الدر اســـة الاســنطلاعية وصياغة الفقرات وفي ضوء ملاحظاتهم عدلت صياغة بعض الفقرات ودمجت بعض الفقرات حتى صــار عـددها(0 (10) فقرة. ولغرض التأكد من مدى شمول هذه الفقرات لقياس السلوك العدواني لدى الأطفال وصلاحيتها في تمثيل هذا السلوك

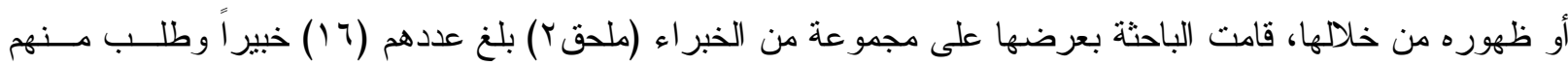

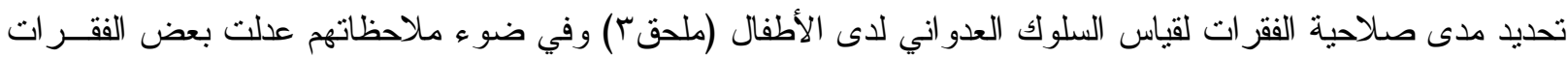

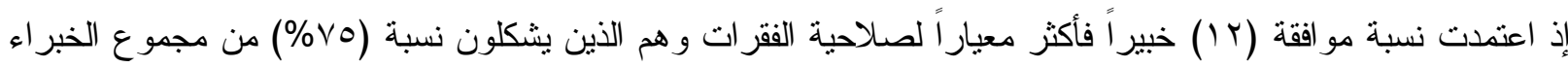
لأن الفرق بين هذا العدد من المو افقين و عدد غير المو افقين وهم (ع) خبر اء بدلالة إحصائية عند مستوى (0. . . ) باستعمال

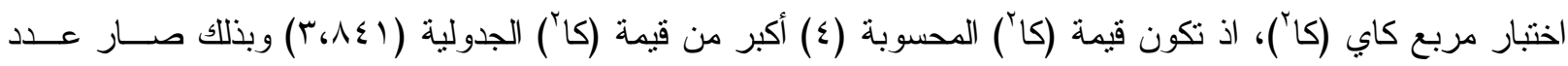

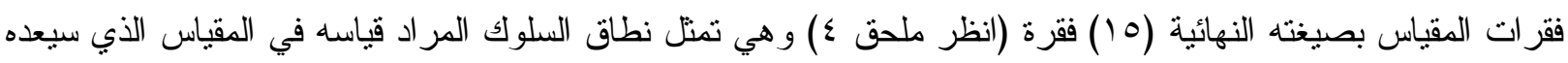

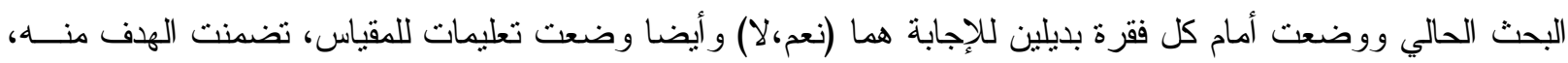

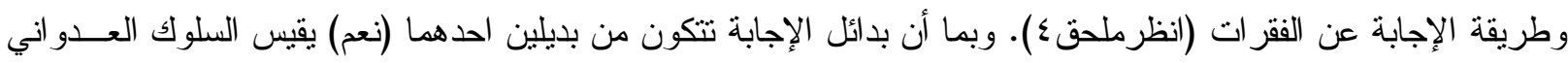

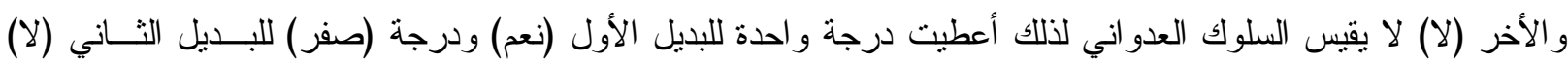

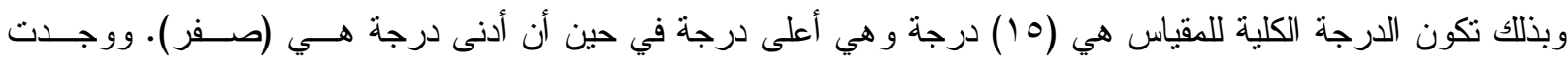

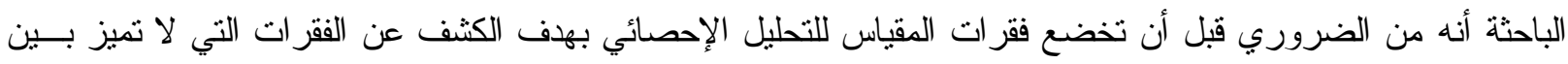

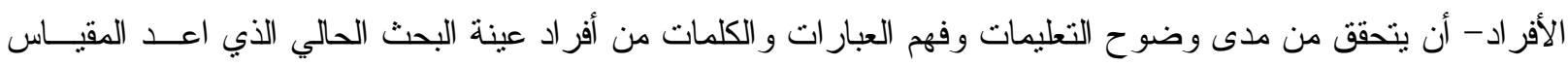

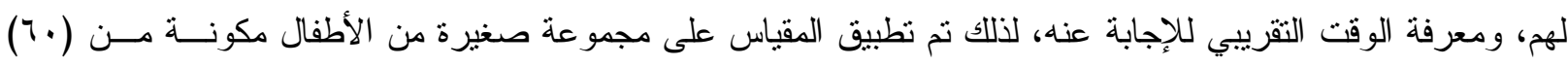

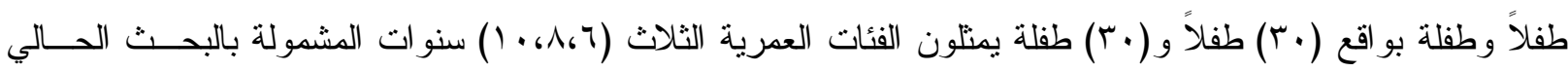

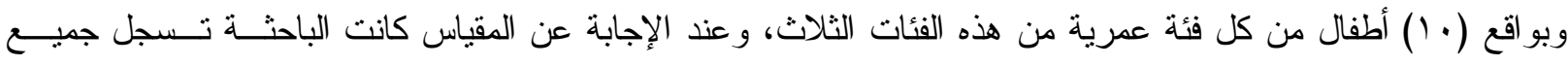

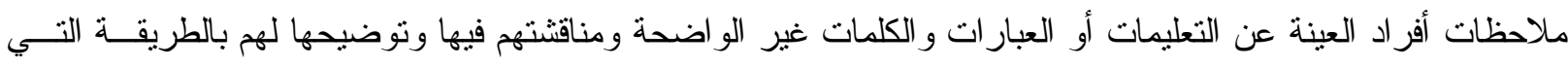

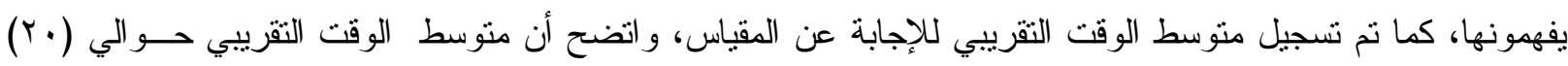

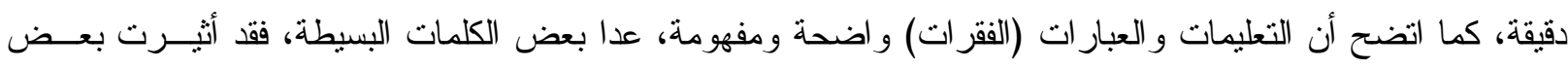
الأسئلة و الاستفسار ات عنها، فتم تبديلها، اذ أصبح المقياس جاهز اً لنطبيقه على عينة اكبر بهدف تحليل فقر اته إحصائياً.

\section{-: Statistical items Analysis تحليل الفقرات إحصائيا}

إن التحليل المنطقي لفقرات المقياس قد لا يكثف عن صدقها بشكل دقيق لكونه يعتمد على الفحص الظاهري للفقرات،

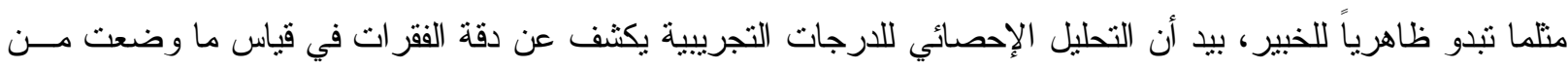

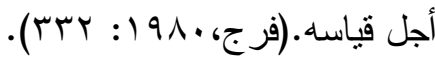

ولتحقيق ذللك حللت الفقر ات إحصائيا، بعد نطبيق المقياس على عينة ممنلة لحساب القوة التمييزية لها، و التحقـق مــن صدقها أو صلاحيتها.

ا ب - الأستاذ المساعد الدكتور تحسين علي حسين

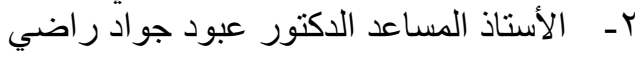

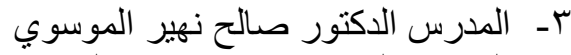
ع - المدرس الدكتور رشيد ناصر خليفه 


\section{1 - القوة التمييزية للفقر ات:}

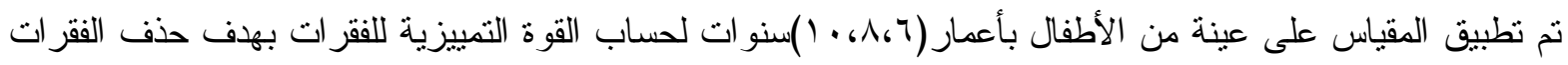

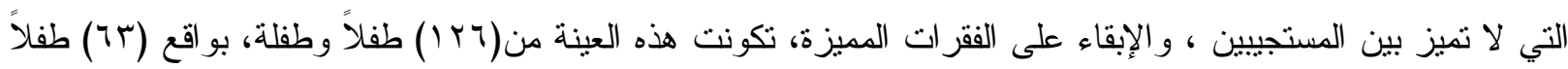

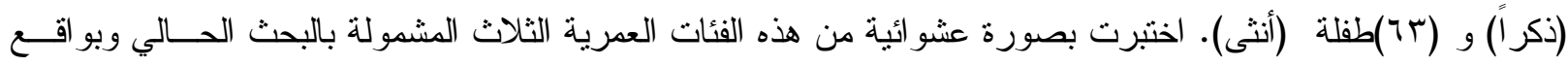

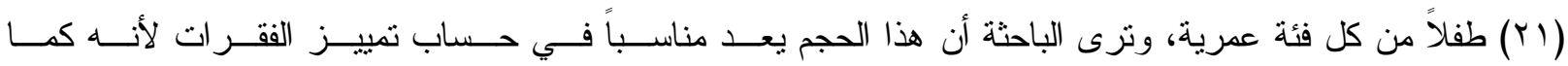

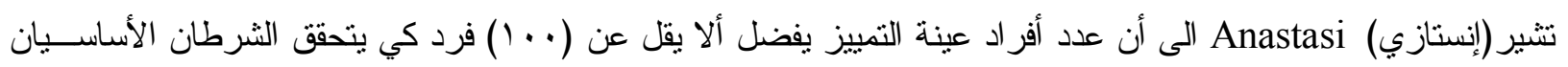

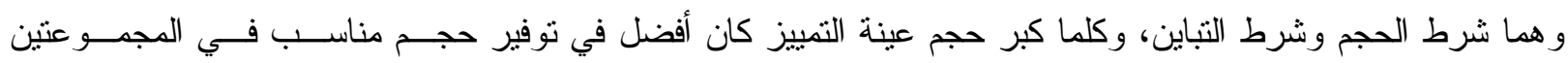

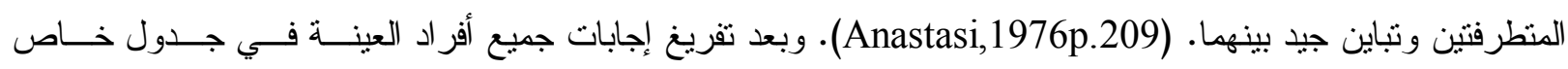
يتضدن درجات الفقر ات والمجموع الكلي لدرجات كل فرد، ونرتيبها من أعلى درجة إلى اقل درجة بحسب الدرجة الكلية،

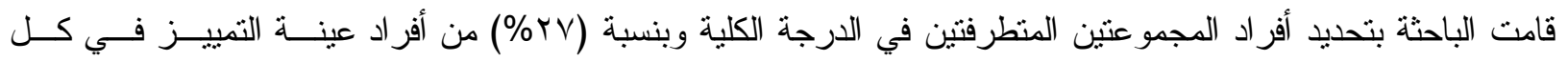
مجموعة. وبذلك صار عدد الأفراد في كل مجموعة (Yr) فرداً وقد امتدت درجات أفر اد المجموعة العليا بين (0) (1) وهي

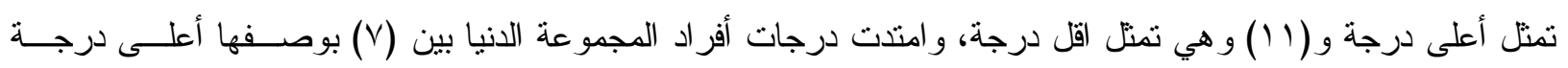

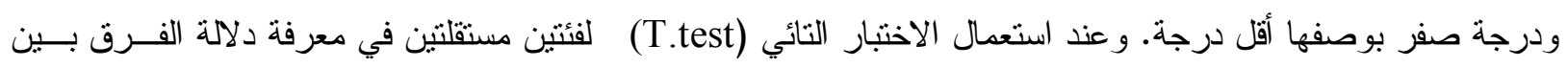

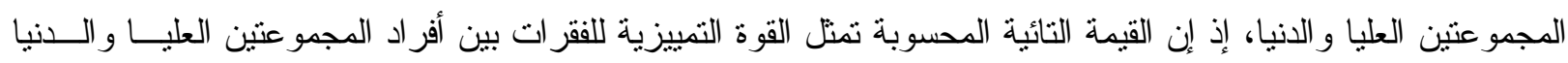
(Edwards,1957,p:153)

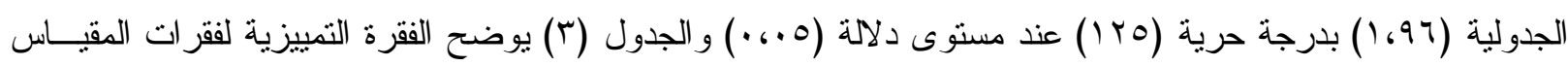
بصيغته النهائية.

الجدول (ب) (بن)

يوضح القوة التمييزية لفقرات المقياس ومعاملات الارتباط بين درجة كل فقرة والدرجة الكلية

\begin{tabular}{|c|c|c|}
\hline معامل الارتباط & الفقرة التمييزية & تسلسل الفقرة فــي \\
\hline$\cdot 6 V Y \leq$ & $\varepsilon_{6} \mid T_{1}$ & 1 \\
\hline .6700 & r.199 & $r$ \\
\hline .0071 & r.r. & $r$ \\
\hline דיVו & $\varepsilon_{6} \Sigma \lambda 1$ & $\varepsilon$ \\
\hline . IVYA & $\varepsilon \leqslant 200$ & 。 \\
\hline . & r.VA. & 7 \\
\hline . 6VY4 & EGTH & $\mathrm{v}$ \\
\hline . .VTr. & דצrאם & $\wedge$ \\
\hline .700 & r.人9) & 9 \\
\hline גזדי. & $r_{6} v \leq 0$ & 1. \\
\hline .071 & "r.r). & 11 \\
\hline . .VYO & E.MYV & $\overline{~ I T ~}$ \\
\hline
\end{tabular}




\begin{tabular}{|c|c|c|}
\hline . & r.VA. & r \\
\hline . GVYA & $\varepsilon 6 \leqslant 00$ & $1 \varepsilon$ \\
\hline אזדה. & $r_{6} v \leq 0$ & 10 \\
\hline
\end{tabular}

\section{r - صدق الفقرات:}

في تحليل الفقر ات احصائياً استعملت الباحثة (معامل ارتباط بيرسون) Pearsons Correlation coefficientبـين درجة كل فقرة و الدرجة الكلية للمقياس بهدف معرفة صدق الفقر ات وكما تشير (انستازي) Anatasi إلى أن ارتباط درجة

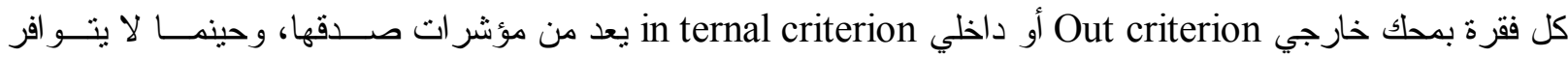

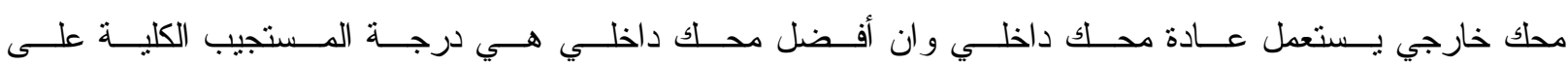

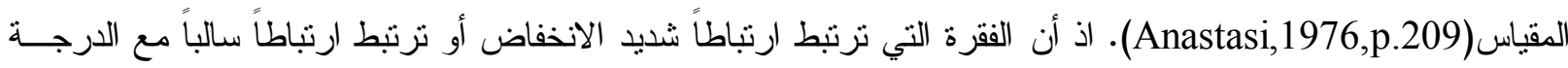

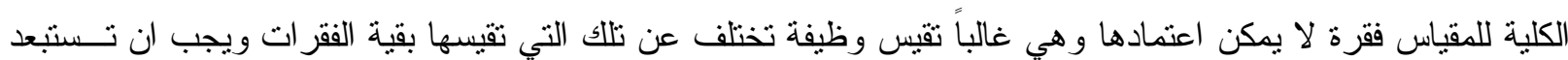

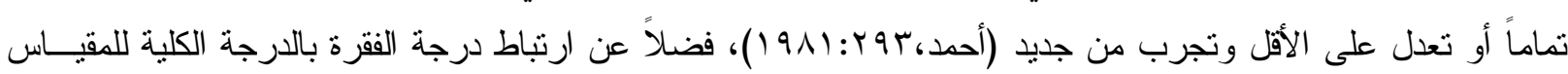

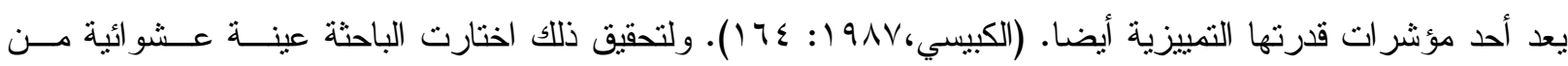

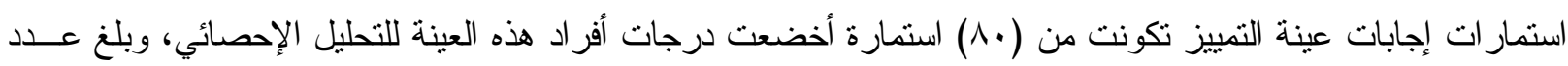

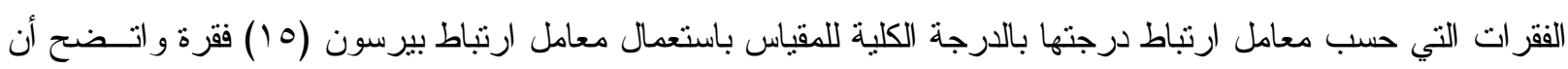
معاملات الارنباط في جميع الفقرات، دالة احصائياً عند مستوى (1، · ) وبعلاقة موجبة فعند الرجوع إلى جدول (جاريت) Garrett

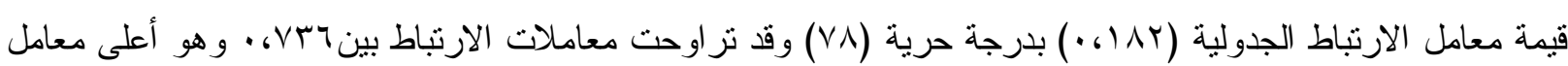

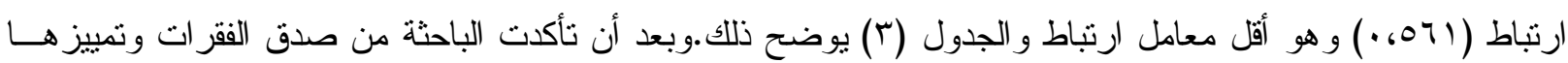

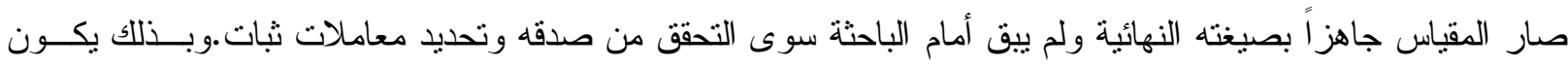

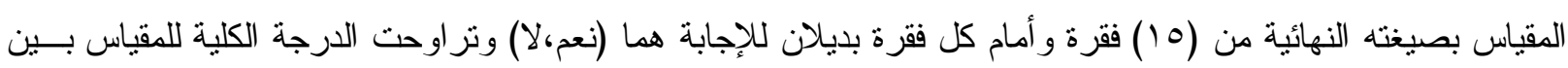
(صفر) كأقل درجة و (10) كأعلى درجة.

ج- صدق المقياس Scale Validity يعد الصدق (Validity) من الخصائص الأساسية للاختبار ات و المقاييس النفسية و التربويــة (Adams,1966,P:144) لأنه يشير إلى قدرة المقياس على قياس ما وضع من أجل قياسه(Ebel,1972,P:408)ذا عمدت الباحثة إلى التحقق مـن صدق المقياس باستخدام الصدق الظاهري Face Validity إذ عرضت فقر ات المقياس البالغة (10) فقرة على لجنة مسن الخبر اء لتحديد صلاحية الفقر ات و اتضح أن جميعها صالحة للقياس اذ حصلت هذه الفقرات على نسبة مو افقة ( . . (\%).

\section{Scale Reliability د- ثبات المقياس}

يعد الثبات من المؤشرات الضرورية للمقياس الموضوعي لكونه يشير إلى الاتساق في مجموعة درجات الاختبار التي

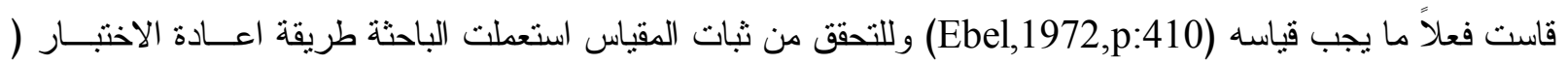
(Test-Retest درجات التطبيق الأول و التطبيق الثاني. اتضح أن معامل الارثباط بينهما يساوي (NV)، • ) وقد يعد هذا المعامل مؤشراً جيداً

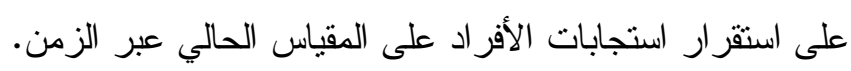
رابعاً-- الوسائل الإحصائية: 
لقد تتو عت الوسائل الإحصائية التي استخدمت في هذا البحث بحسب تتوع منطلباتها و استخرجت النتــائج الإحــصائية

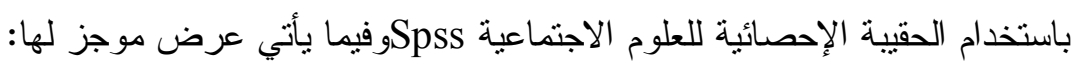

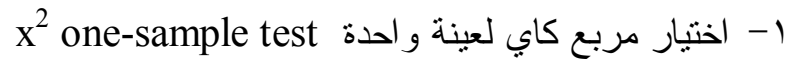
استخدم في معرفة دلالة الفرق بين عدد الخبر اء الذين و افقو ا على فقرات المقياس و الذين لم يو افقو ا عليها.

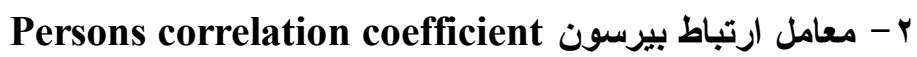
استخدم في حساب معامل الثبات بطريقة اعادة الاختبار (Test-Retest) ومعامل ارتباط درجة كل فقــرة بالدرجــة الكلية للمقياس. ب- الاختبار التائي T.test لعينتين مستقلتين:

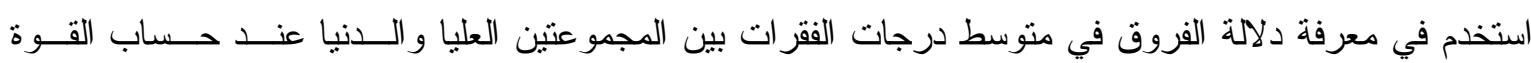
التمبيزية لفقر ات المقياس ومعرفة دلالة الفروق بين متغير الجنس (ذكور ،إناث). ع - تحليل التباين one-way variance analysis استخدم في معرفة دلالة الفرق بين متغير العمر (7، (1، • ( ) سنوات. عرض النتائج وتفسيرها:

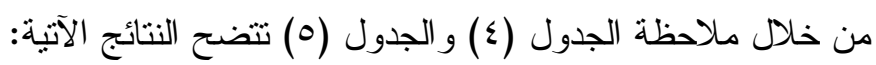

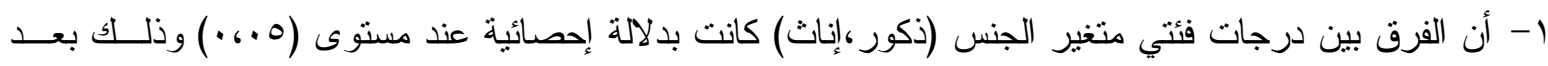

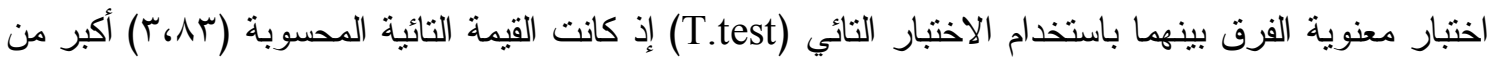

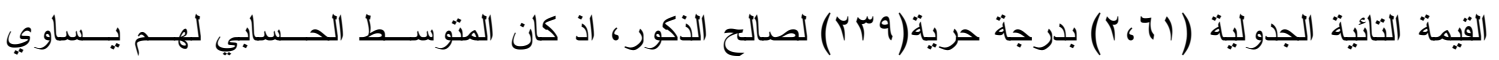

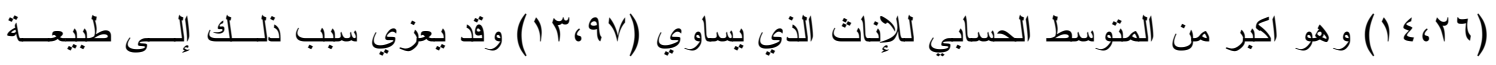

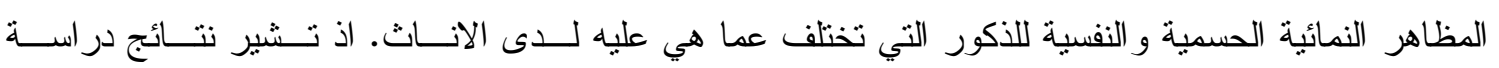
(الجماس) الى أن السلوك الانفعالي النفسي لدى الأطفال الذكور يكون أكثر قساوة و عدو انية مــن الإنــاث تجــــاه

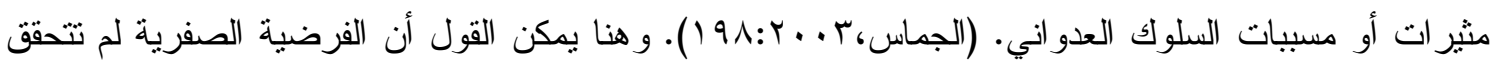
وتقبل الفرضية البديلة.

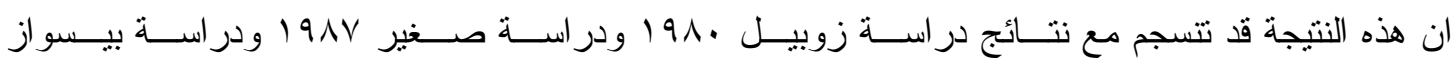

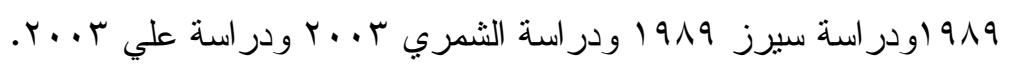

جدول (飞)

يوضح قيمة الاختبار النائي T.testبين متغير الجنس (ذكور ، إناث)

\begin{tabular}{|c|c|c|c|c|c|c|c|c|}
\hline نوع الدلالة & الدلالة & قولية ت الجد & 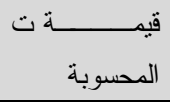 & درجة الحرية & 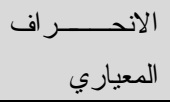 & الحسابي المتوســـــ ط & العدد & الجنس \\
\hline \multirow[t]{2}{*}{ دال إحصائياً } & \multirow[t]{2}{*}{.6 .0} & \multirow[t]{2}{*}{ T.TI } & \multirow[t]{2}{*}{ r.人 } & \multirow[t]{2}{*}{$r r q$} & r.TH & $1 \leq 647$ & 1.1 & ذكور \\
\hline & & & & & T,Y & $1 \pi .9 V$ & rTו & إناث \\
\hline
\end{tabular}

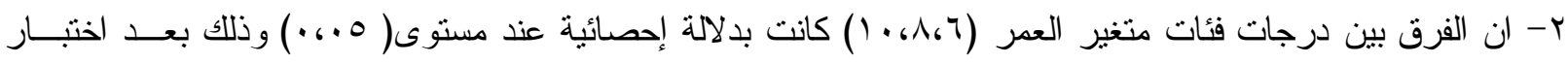
معنوية الفروق بينهما باستخدام تحليل التباين البسيط one-way variance analysis ، اذ كانت النسبة الفائية المحسـسوبة

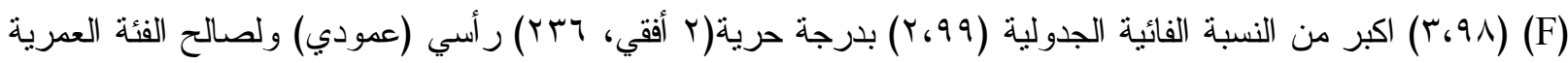




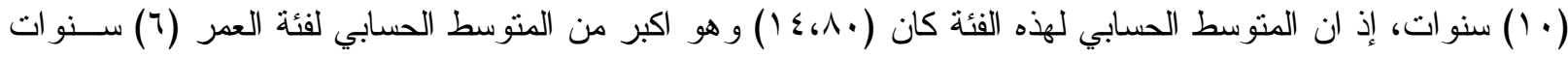

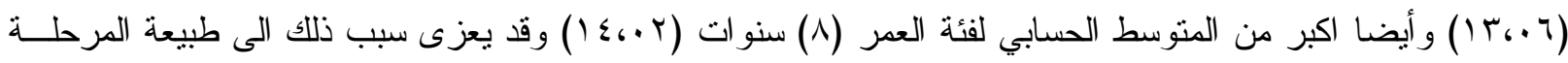

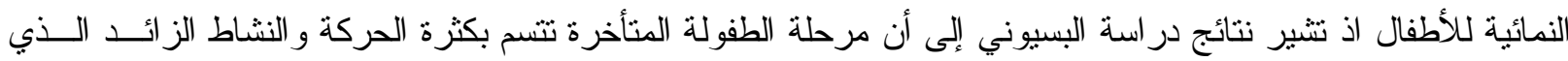

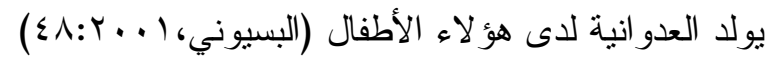

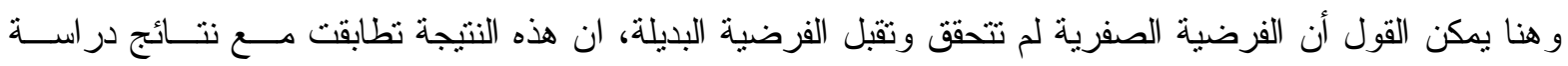

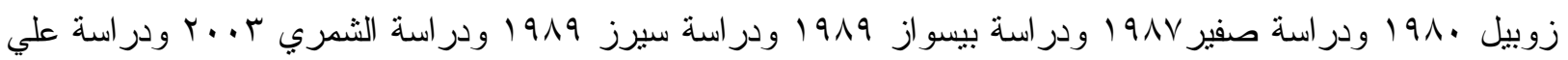

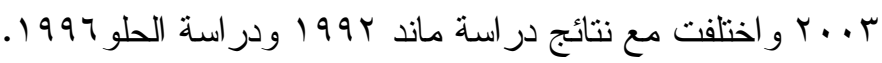
جدول (0) (1)

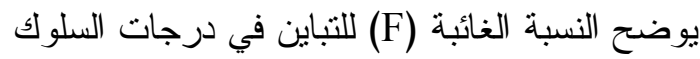

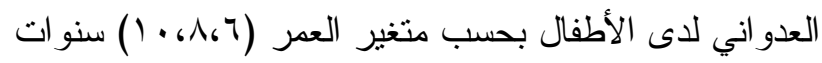

\begin{tabular}{|c|c|c|c|c|c|c|c|}
\hline نوع الدلالة & مستوى الدلالة & النسبة الفائية & النسبة الفائية & $\begin{array}{c}\text { المربعات ستو m.s } \\
\text { m }\end{array}$ & $\begin{array}{c}\text { الحرية د.f درة d } \\
\text { d }\end{array}$ & $\begin{array}{c}\text { المربعات S.S } \\
\text { S.S }\end{array}$ & مصدر النباين \\
\hline \multirow[t]{3}{*}{ دال إحصائياً } & \multirow[t]{3}{*}{.6 .0} & \multirow[t]{3}{*}{$r .99$} & \multirow[t]{3}{*}{$r .91$} & KA, MT & $r$ & $10, .9$ & بين المجموعات \\
\hline & & & & $r A_{6}, q$ & 4זו & $1 \cdot A_{6} \cdot \varepsilon$ & داخل المجمو عات \\
\hline & & & & & IrA & 194.14 & الكلى \\
\hline
\end{tabular}

الاستنتاجات

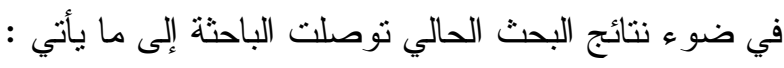

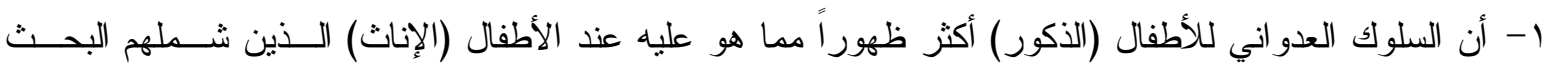

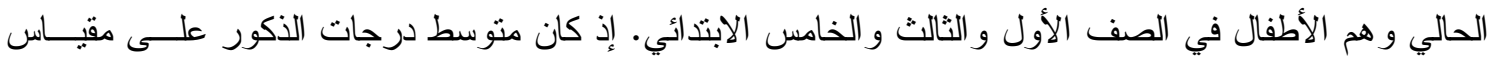

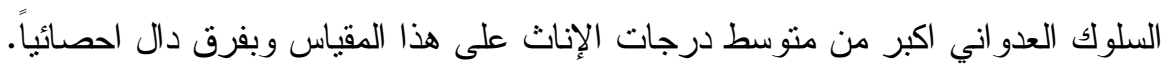

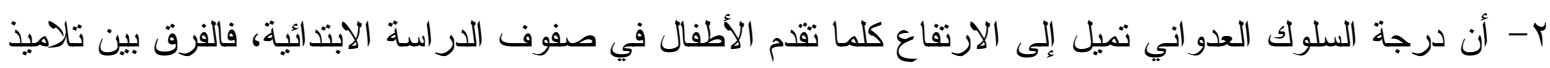

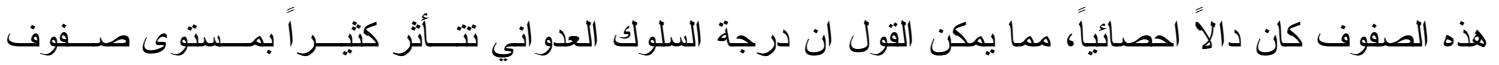
الدر اسة الابتدائية.

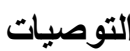

$$
\begin{aligned}
& \text { في ضو ضو نتائج البحث، نوصي الباحثة بما يأني: } \\
& \text { 1- ضرورة اتباع استر اتيجيات التربية السليمة في التعامل مع الأطفال. }
\end{aligned}
$$

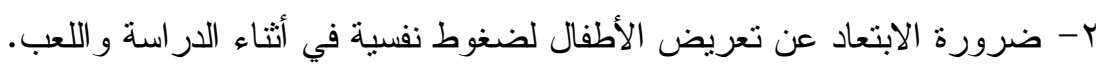

$$
\begin{aligned}
& \text { r- ب- ضرورة الاهتمام بالصحة النفسية للأطفال. } \\
& \text { ع - ضرورة تعيين مرشد نربوي في كل مدرسة ابتدائية. }
\end{aligned}
$$

ه- ضرورة فتح مركز نفسي تخصصي لعلاج ظاهرة العدو ان و العنف لدى الأطفال في كل محافظة أو قضاء.

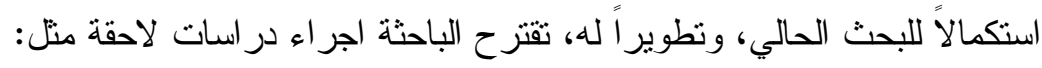

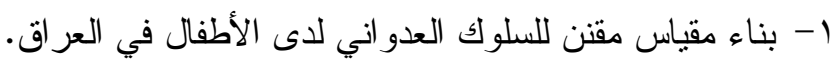

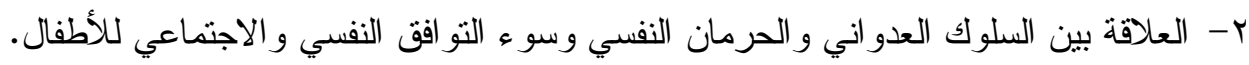


r- العوامل المؤثزة في نمو السلوك العدواني لاى الأطفال.

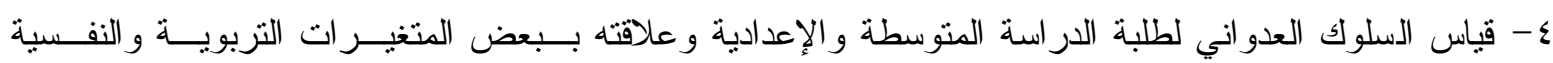

و الاجتماعية.

ملحق (1)

جامعة و اسط

كلية التربية

قسم العلوم التزبوية و النفسية

م/ در اسة اسنطلاعية

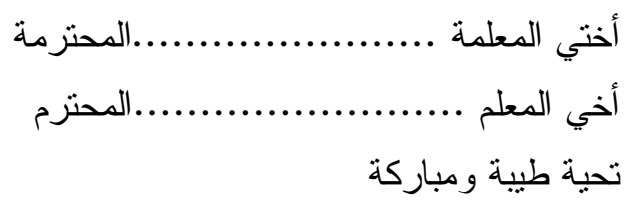

تروم الباحثة أجر اء دراسة عن السلوك العدواني لدى الأطفال، ولكونهم أكثر احتكاكاً ونو اصلاً بالأطفال نرجو الإجابة

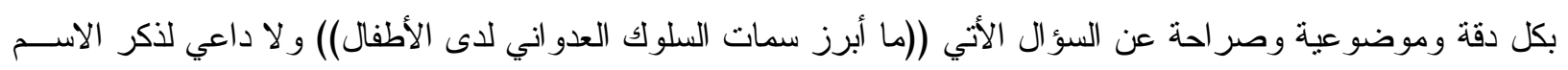
شاكرين تعاونكم معنا خدمة للبحث العلمي.

د. أسيل عبد الكريم

ملحق (r)

\begin{tabular}{|c|c|c|}
\hline الجامعة و الكلية & أسماء لجنة الخبر اء & $ت$ \\
\hline بغداد - كلية التربية & الأستاذ الدكتور صاحب الجنابي & 1 \\
\hline بغداد - كلية التربية & الأستاذ المساعد الدكتور عبد الحسين الجبوري & r \\
\hline بغداد - كلية التربية & الأستاذ المساعد الدكتور محمد أنور السامر ائي & $r$ \\
\hline و اسط / كلية التربية & الأستاذ المساعد الدكتور تحسين علي حسين & $\varepsilon$ \\
\hline و اسط / كلية التربية & الأستاذ المساعد الدكتور عبود جو اد راضي & ○ \\
\hline و اسط / كلية النزبية & الأستاذ المساعد الدكتور عباس مرير وسيج & 7 \\
\hline و اسط / كلية التربية & المدرس الدكتور صالح نهير الموسوي & $\mathrm{v}$ \\
\hline و اسط / كلية التربية & المدرس الدكتور رشيد ناصر خليفه & $\wedge$ \\
\hline بابل / كلية التربية & المدرس الدكتور جاسم ناصر العقيلي & 9 \\
\hline بابل / كلية التربية & المدرس الدكتور علي حميد الزبيدي & 1. \\
\hline بابل / كلية التربية & المدرس الدكتوركمال برسيم علي & 11 \\
\hline بابل / كلية التربية & المدرس الدكتورفؤاد جمال حمزة & ir \\
\hline كربلاء / كلية التربية & المدرس المساعد أحمد فلاح الخرساني & r \\
\hline كربلاء / كلية التربية & المدرس المساعد بهاء حسين الصافي & $1 \leq$ \\
\hline القادسية / كلية التربية & المدرس المساعد محمد جاسم دعبول & 10 \\
\hline القادسية / كلية التربية & المدرس المساعد ناجي منشد حسن & 17 \\
\hline
\end{tabular}




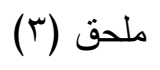

م ا ملاحية الفقرات

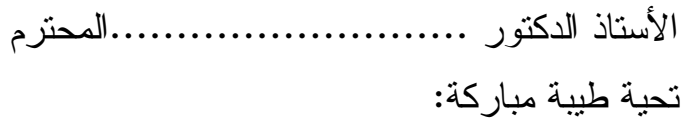

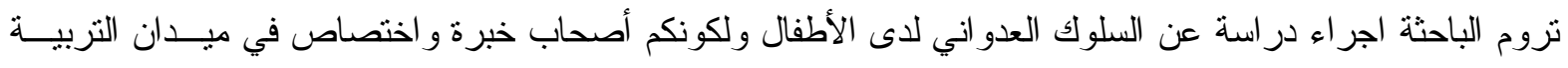

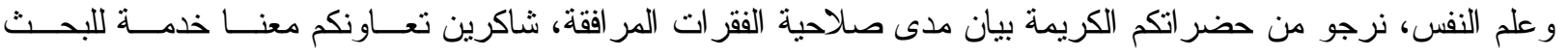
العلمي

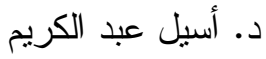

ملحق (๕)

م/ المقياس بصيغته النهائية

عزيزي التلميذ. عزيزتي التلميذة

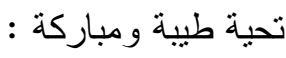

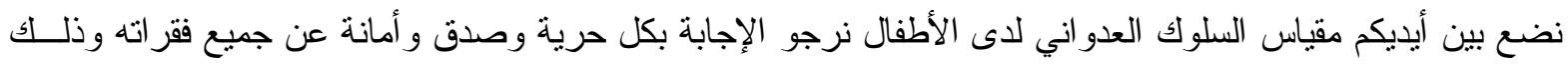
بوضع علامة ( ل ل ) نحت أحد البديلين (نعم) (لا) هذا ولكم منا جزيل الثكر و الامتتان و لا داعي لذكر الاسم و الاكتفاء بذكر الجنس و العمر في الحقل المخصص لهما.

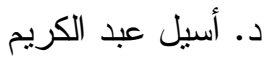

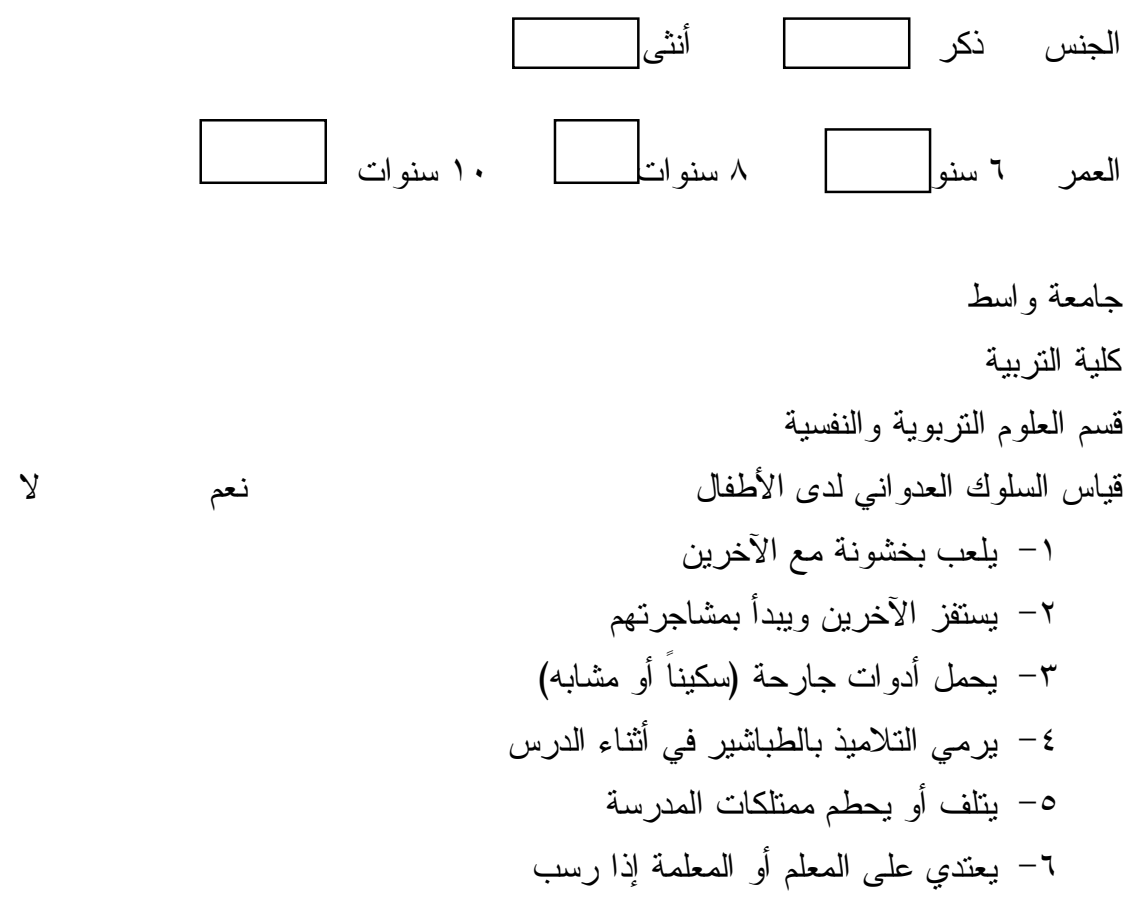


- يضرب التلاميذ في أماكن جسمية خطيرة عند المشاجرة معهم

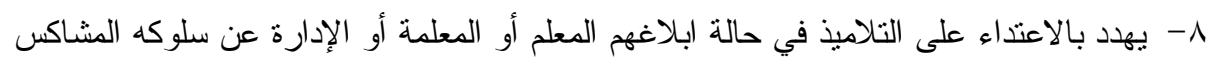

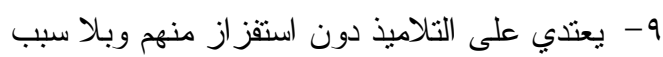
.

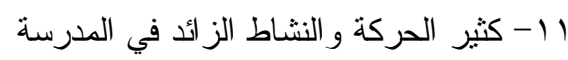

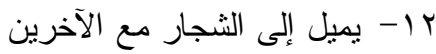
ז ا - يميل إلى القفز من حائط المدرسة الفئ ع ا- يشاهد أفلام العنف 10 - برد على المعلم أو المعلمة بصلافة إذا سألوه عن تقصبره في أداء و اجباته المدرسية

الدكتورة أسيل عبد الكيم

\section{المصادر}

! . أحمد، محمد عبد السلام (1911)، القياس النفسي والتزبوي، القاهرة، مكتبة النهضة المصرية. Y. إسماعيل، محمد عماد الدين، ونجيب اسكندر ، (9V1) (1)، كيف نربي أطفالنا، النتشئة الاجتماعية للطفل في الأسرة، القاهرة: دار النهضة العربية.

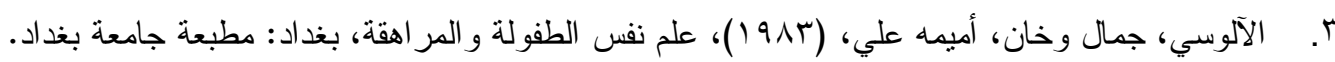

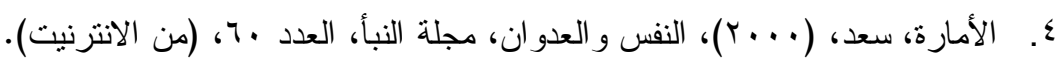

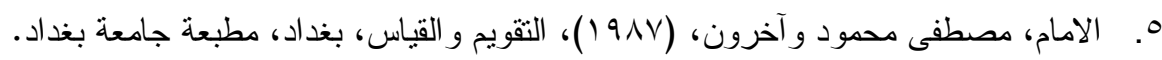

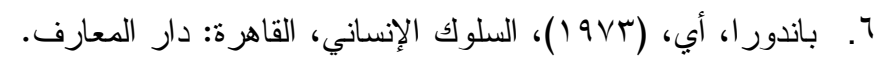

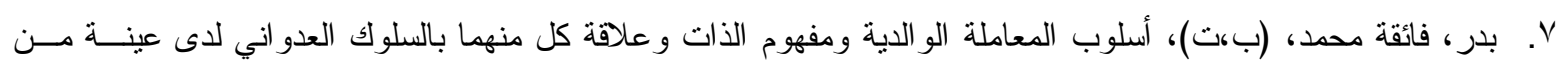
تلميذات المرحلة الابتدائية بجدة، السعودية.

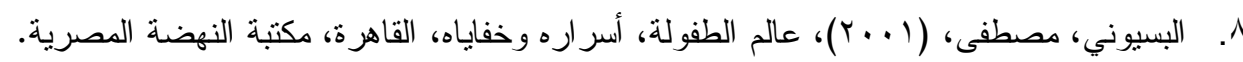
9. جاسم، عبد السلام جودت، (919 (1)، اثر العقوبة في احداث السلوك العدواني وعلاقة ذللك ببعض أساليب المعاملة الوالدية،

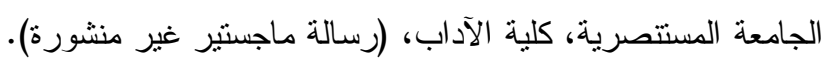

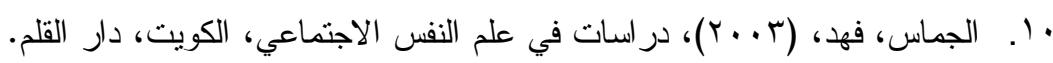

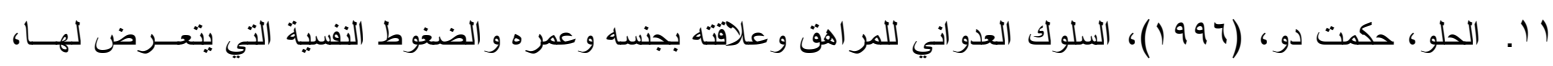
جامعة بغداد، كلية التربية ابن رشد، (أطروحة دكتور اه). r r أ. خيري، السيد محمد، (90V (19)، الإحصاء في البحوث النفسية و التربوية والاجتماعية، القاهرة، مطبعة دار التأليف.

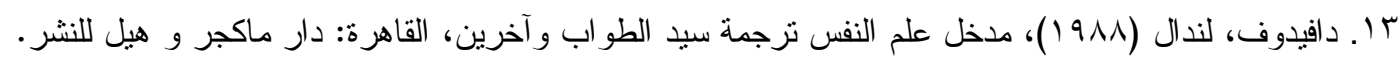

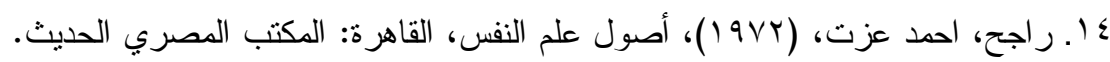

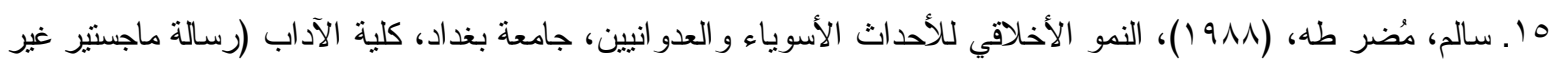

$$
\text { منشورة). }
$$

17. سنتور ، انتوني (9V0) (1)، العدوان البشري، نرجمة محمد احمد غالي وآخرين، الهيئة المصرية العامة للكتاب.

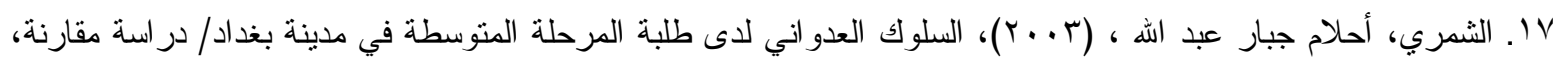
جامعة بغداد ، كلية التربية للبنات، (رسالة ماجستير). 


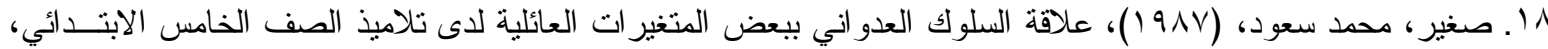

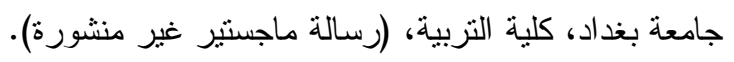

9 1. الطويل، عزت عبد العظيم (V . . r) سيكولوجية العدوان. مصر ، القاهرة، مكتبة النهضة المصرية.

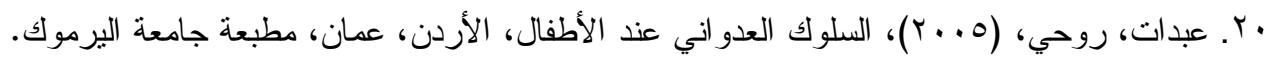

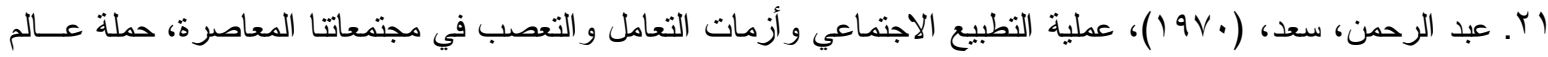

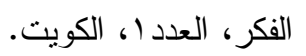

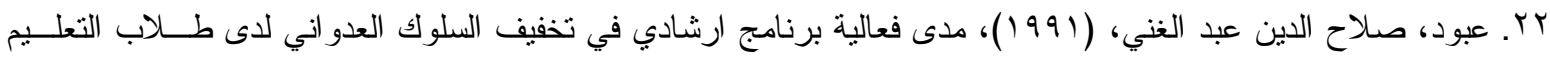

$$
\text { الأساسي، مصر ، كلية النزبية، (رسالة ماجستير ). }
$$

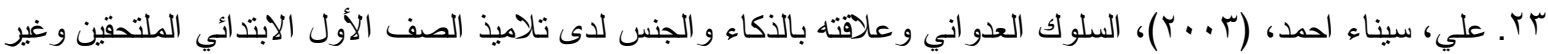

الملتحقين برياض الأطفال، جامعة بغداد، كلية التزبية للبنات، (رسالة ماجستير ).

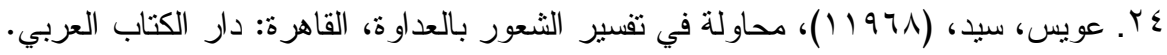

م r. العيسوي، عبد الرحمن محمد، (999 (19)، علم النفس الأسري، الإسكندرية: دار المعرفة الجامعية.

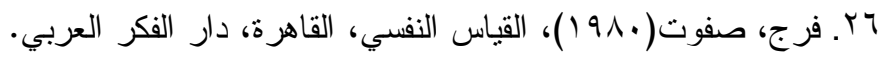

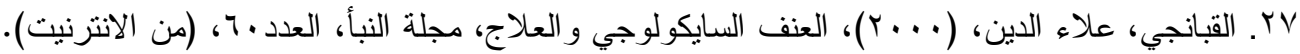

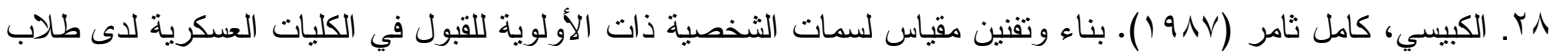

الصف السادس الإعدادي في العر اق (أطروحة دكتور اه غير منشورة). جامعة بغداد، كلية التزبية.

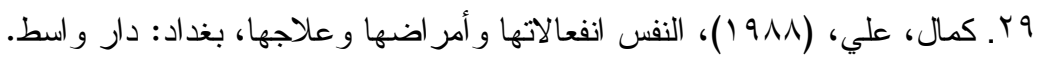

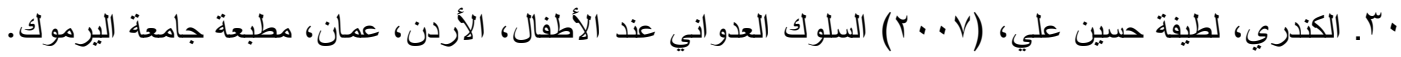

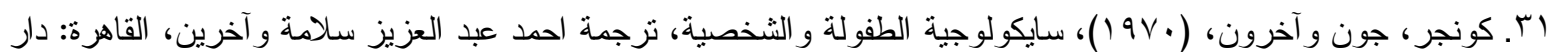

$$
\text { النهضة العربية. }
$$

r r.. محمود، حمدي شاكر ، (991())، مبادئ علم نفس النمو في الإسلام، السعودية: دار الأندلس للنشر و التوزيع.

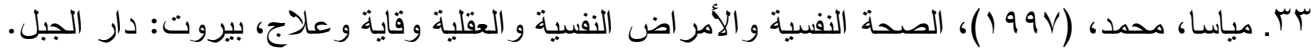

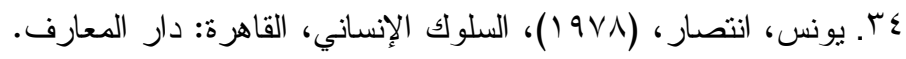

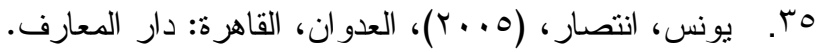

36- Anastasi. A.(1976): psychological Testing, New york Macmillan.

37- Biswas. (1989).Drection of Aggression of school-Going Adolescents Related to Family Tenion:Areaof Residence and sex:

Acop arative study,in Manas,vol.1

38- Ebel,A.1.(1972) Essential so \& Education al Measurwment. New Jersy, Englewood.

39- Edwards, A.L.(1957) Teaching ues of attitude constrnuction., New york,Appletion inc.

40-Good, carterr,(1959) Dictionary of Education,2nded.New york, McGraw - Hill.

41- Hurlock,Elizabeth,(1964), child development, Fourth Edition, New York.

42-Mind.k(1992).Aggression in preschoolers ,in:Jam.Acad child \&Addesc. Psychi.

43- Medinus, G.R\&c. Johnson.(1976), child and Adolescent psychology, New york, wiley.

44-Mussen p.H.congerj. \&keganj(1978), child. Development Personality, fifth edition, Harper, and Rwo publishers New york

45- Zwiebel,Sarh,D.Sw. (1980), The Relation Between Matcmal Behaviours and aggression in sons,Blaok and Puer to Riccan

Families, In Dissett: oabstracts In temational, vol40,N012. 